SENSEMAKING \& IDENTITY MANAGEMENT AMIDST

MAJOR ORGANIZATIONAL CHANGE

A Thesis presented to
the Faculty of the Graduate School at
the University of Missouri-Columbia
In Partial Fulfillment
of the Requirements for the Degree
Master of Arts
by
MADELINE PRINGLE
Dr. Rebecca Meisenbach, Thesis Supervisor


The undersigned, appointed by the dean of the Graduate School, have examined the thesis entitled

\section{SENSEMAKING AND IDENTITY MANAGEMENT AMIDST MAJOR ORGANIZATIONAL CHANGE}

Presented by Madeline Pringle,

A candidate for the degree of Master of Arts,

and hereby certify that, in their opinion, it is worthy of acceptance.

Professor Rebecca Meisenbach

Professor Debbie Dougherty

Professor Andrea Figueroa-Caballero

Professor Sarah Diem 


\section{Acknowledgements}

A lot of people in many areas of my life have helped get me through this journey. First off, my committee-Rebecca, Dr. D., Drea, and Dr. Diem. I appreciate you all for sticking with me through the ups and downs of this process. I want to pay a special thanks to Rebecca Meisenbach, my advisor, for being there every step of this year plus endeavor. From helping me think of ideas for my thesis to countless revisions of chapters to weekly zoom calls talking through concepts and ideas, Rebecca has done this all with a smile on her face. I am very thankful to have had her by my side in this process and I am very excited to continue working with her for my Ph.D.!

To all my friends in and outside of academia, I am thankful for you all! Whether it was conducting pilot interviews with you, talking on the phone/over zoom about my progress (or lack thereof), or just venting about the woes regarding this process, so many of you were instrumental in helping me push through the hard days. Much love to you all.

Although talking about writing a thesis was difficult at times, the constant emotional support from my family is what allowed me to get where I am today. The constant checking in on how I was doing with the process by my mom, dad, brother, grandparents, and the like is something I greatly appreciated.

Lastly, to my partner Ryan and my dog Barley, I love you both so much! I am not sure I would have been able to make it through this whole thing as well as I did without you both. Thank you for allowing me to talk through research at the dinner table and my difficulties with the thesis process before bed. I am so grateful to have you both in my life and I can't wait to continue doing life together. Onto the next chapter! 


\section{TABLE OF CONTENTS}

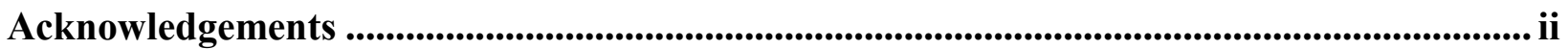

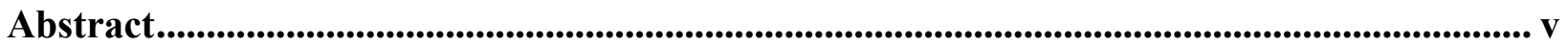

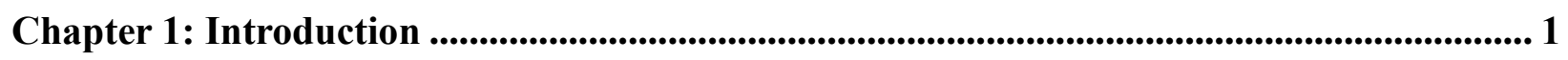

Societal Problem ............................................................................................. 1

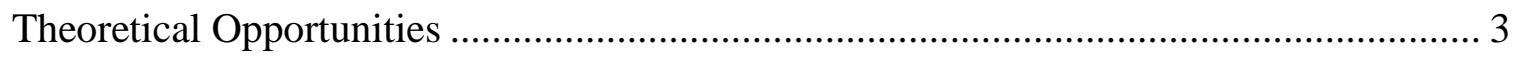

Project Overview \& Conclusion .................................................................... 4

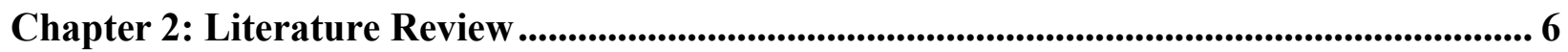

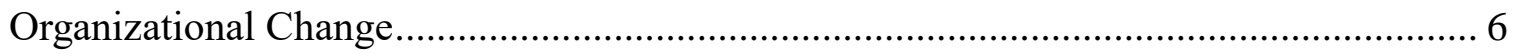

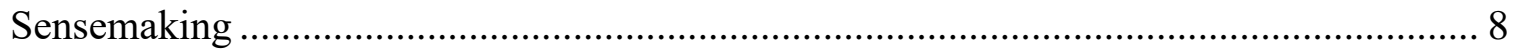

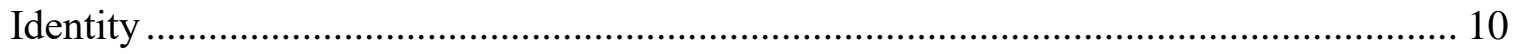

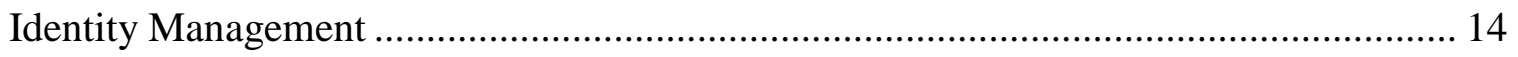

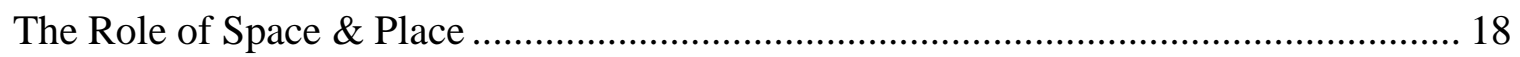

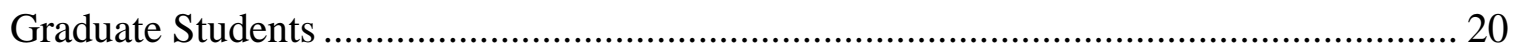

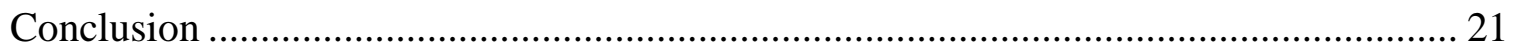

Chapter 3: Methodology \& Methods ...................................................................................... 22

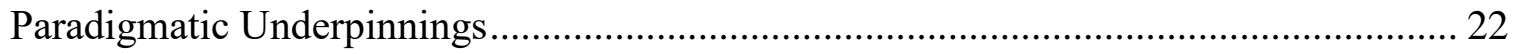

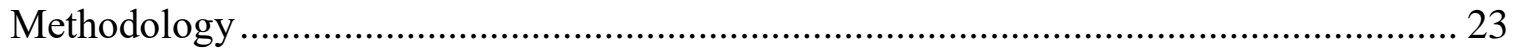

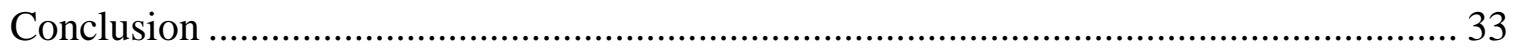

Chapter 4: Findings on Sensemaking \& Identity Management (RQ1 \& RQ2) ................... 34

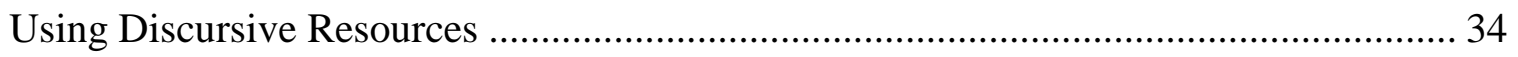

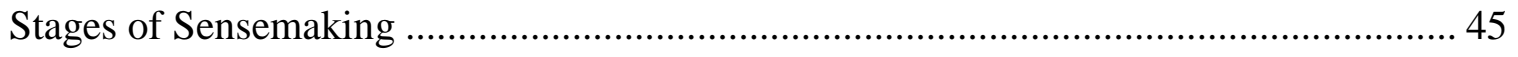

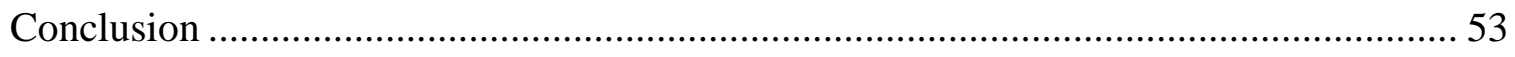

Chapter 5: Findings on the Role of Place (RQ3) ....................................................................... 54

Thinking of What Once Was: Creating a Present Absence ......................................... 54 


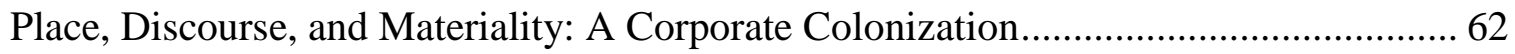

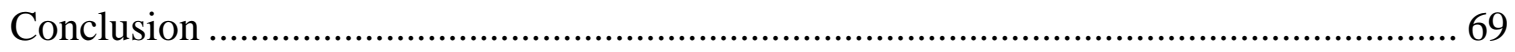

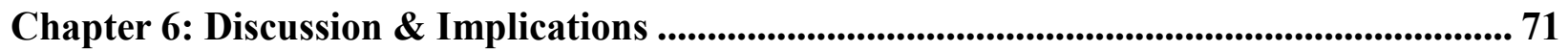

Discussing Sensemaking and Identity Management Processes .................................. 71

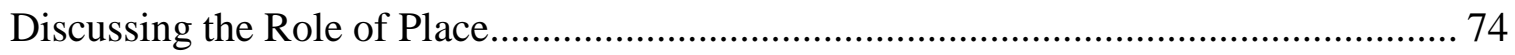

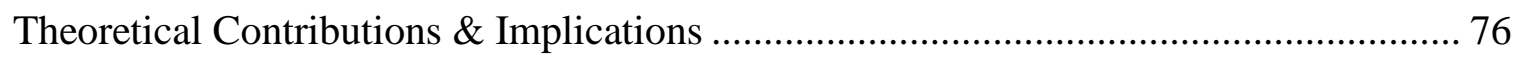

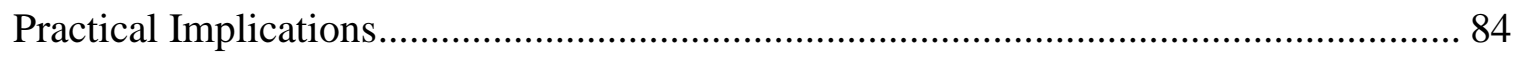

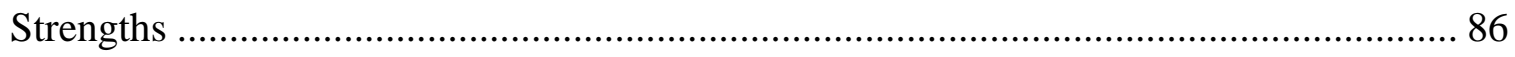

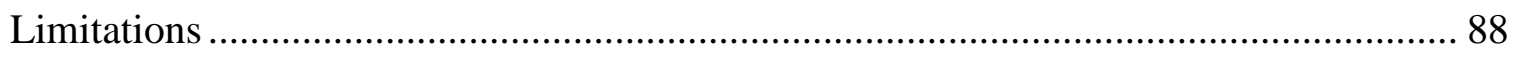

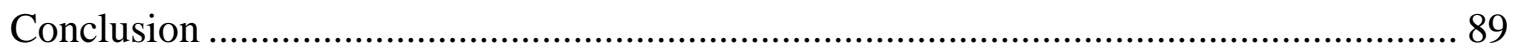

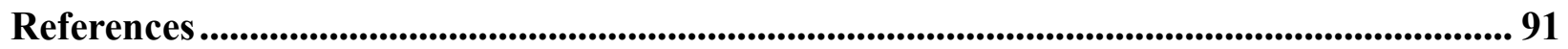

Appendix A: Interview Protocol ....................................................................................................... 104

Appendix B: Participant Demographics............................................................................................. 107 


\begin{abstract}
Organizational change is inevitable and its impacts will affect all members, albeit to different degrees. These changes also bring about uncertainty, especially as it pertains to one's organization-based identities. However, when studying change and identity, organizational communication scholars have often missed studying the interplay of one's many organizationbased identities and how these are made sense of and managed amidst major organizational change. This thesis employs a phronetic-iterative methodology to analyze 16 semi-structured interviews with U.S. graduate students to understand how they have made sense of and managed their organization-based (i.e., graduate student, teaching assistant/instructor, department, university) identities after the COVID-19-induced transition to fully online education in Spring 2020. Analysis of this data suggested that participants used two types of ideal self discursive resources to make sense of and manage these identities, while also experiencing their sensemaking and identity management processes in two distinct stages. Additionally, participants revealed the importance of organizational places as it pertained to making sense of this change and its impacts. With these findings, this thesis extends theoretical work surrounding sensemaking, identity, and place, especially as it pertains to organizational change and provides practical recommendations for organizational leaders in academia to assist some of their highlyimpacted and identity-precarious populations--graduate students.
\end{abstract}




\section{Chapter 1: Introduction}

Change is inevitable. In her book on organizational change, Lewis (2019) wrote that "change is something we sometimes seek, sometimes resist, and sometimes have thrust upon us" (p. 10). In research, change is often regarded in two ways: unplanned and planned (Lewis, 2019). With the onset of the COVID-19 pandemic, higher education institutions across the United States and the world responded to this unplanned, unprecedented virus by quickly "planning" and implementing a major organizational change--transitioning classes online for the remainder of the 2020 school year. By the end of March 2020, over 1,100 college campuses across the United States cancelled or moved classes strictly online, impacting over 14 million college students at the undergraduate and graduate levels (Hess, 2020; Smalley, 2020). This major organizational change to education institutions will have lasting impacts, especially to their members in identityprecarious positions, such as graduate students. Immediate work is needed to study how these organizational members have been impacted by this change and how they have made sense of it.

\section{Societal Problem}

"I have never felt so depressed, anxious, and inadequate."

"The feelings of being useless and left out...are even worse in times like these." These are just two quotes from graduate students in a recent study during the COVID-19 pandemic (Zahneis \& June, 2020, p. 1). The National Science Foundation found that during the COVID-19 pandemic, two-thirds of graduate students reported low well-being, while a third expressed experiencing symptoms of depression and anxiety (Zahneis \& June, 2020). Even outside the pandemic, graduate students have been identified as six 
times more likely to experience anxiety or depression than the general public (Flaherty, 2018).

Even without a pandemic, graduate students face many challenges attached to their role, including difficult work, social isolation, feeling inadequate, and a hypercompetitive and shrinking job market (Flaherty, 2018; Langin, 2020). In addition, graduate students must negotiate identities that span across multiple contexts, including one's university, their department, and the classrooms in which they alternately work roles as students and as instructors (Foot et al., 2014). Past research suggests that how graduate students internalize and manage these many identities affects their ability to persist through their respective graduate programs (Austin, 2002; Baker \& Pifer, 2011; Foot et al., 2014). Because of COVID-19-related changes to academic structures, the already difficult matter of managing one's many graduate student identities became increasingly more difficult (Poulton \& Yoo, 2020; Zahneis, 2020). To support graduate students, more research must be done on how current students are handling the organizational change associated with the onset of the COVID-19 global pandemic.

Although the COVID-19 pandemic will eventually subside, the changes resulting from the pandemic will have long-lasting implications. Certain educational programs may decide to make these transitions more permanent. If this is the case, educational institutions need to know how this type of large-scale change impacts organizational members. If studies can show how U.S. graduate students have made sense of their identities with the institution after moving in-person programs fully online, researchers can provide this information to institutional leaders, so they can better understand and assist some of their main stakeholders, graduate students. 


\section{Theoretical Opportunities}

In the wake of the COVID-19 pandemic, Stephens et al. (2020) spoke of "renewed interest" in organizational change work (p. 448). These authors articulated research opportunities about studying sensemaking of stakeholders' "unique experiences pertaining to COVID-19 induced changes" (Stephens et al., 2020, p. 448). In conducting this thesis, I answer this research call, specifically studying how graduate students made sense of and managed their specific organization-based identities (i.e., graduate student, teaching assistant/instructor, department, university) amidst the transition to COVID-19induced online learning in Spring 2020.

Organizational change, identity threats, and organizational crises all trigger sensemaking (Maitlis \& Christianson, 2014). As the transition to COVID-19-induced online learning touches on all the above components, this disruption offers a rich site to study people's sensemaking. Alvesson et al. (2008) suggested that questioning one's identity/ies is most prominent during organizational change. Rooney et al. (2010) and Chreim (2002) both argued that organizational change alters organizational members' identities. Researchers have examined a range of organizational changes, including acquisition and mergers (Edwards et al., 2017; Hinsley, 2017; Pepper \& Larson, 2006; Pierce \& Dougherty, 2002), implementation of new organizational services (Barrett \& Stephens, 2017; Rooney et al., 2010), transitioning to new jobs (Ibarra, 1999), struggling organizations (Williams \& Connaughton, 2012), and implementation of new management (Ashcraft, 2005). These studies analyzed organizational change and its impact on organizational identity, but they skip over assessing the interplay of the other organization-based identities members have. 
Members of an organization do not just have one, all-powerful form of identity; there are "many hats of organizational membership" (Ashforth \& Johnson, 2001, p. 31). For example, I am not just a University of Missouri Tiger, but am also a white, female graduate student, a teaching assistant, and a member of the communication department. My identities may operate at different levels, have varying salience depending on the context, and may even be conflicting or contradict one another. Too often, organizational communication research focuses on just one form of identity and does not assess the multiple organization-based identities at play in any given context (Lammers et al., 2013; Vough, 2012). If researchers reduce these many different identities together into one organizational identity, rich information about how these identities differ and interact with one another may be missed. This study hopes to address this matter by interviewing U.S. graduate students to learn how they have made sense of and managed their organization-based identities during the transition to online teaching and learning associated with the COVID-19 pandemic.

\section{Project Overview \& Conclusion}

This major organizational change is important to study from a communicative perspective because if this is a more permanent change induced by the COVID-19 pandemic, it is imperative to learn how some of the most affected members make sense of and manage their organization-based identities amid this change. Graduate students are major stakeholders in higher education institutions. By studying how heavily affected organizational members have made sense of their organization-based identities due to the change, I hope to bring new insight to organizational communication scholarship and provide practical information to assist educational institutions on ways they can support 
graduate students, better enabling them to persist through their programs, especially during these trying times.

The rest of this thesis is divided into chapters, each providing an important component to the overall project. Chapter two introduces the core concepts and theories that create the rationale for this study. The third chapter focuses on the methodology and methods used. My findings are presented over two chapters, with themes covering the first two research questions on sensemaking and identity management in chapter four, and themes from research question three in chapter five, addressing the possible role place plays in these processes. The final chapter, chapter six, focuses on the discussion and implications of my research. 


\section{Chapter 2: Literature Review}

In this chapter, I review the concepts and theories surrounding organizational change, sensemaking, identity, and space and place. Each of these areas provides necessary background, and through discussion of each of these sections separately and together, I produce a rationale for my study.

First, I will briefly speak to the literature on organizational change. I address the different ways organizational change has been studied within the communication field. I suggest how major organizational change results in the need for sensemaking, this study's main theoretical framework. I discuss why sensemaking is needed, sensemaking's process, and its components. After discussing sensemaking, I focus on one of sensemaking's main components, that being identity construction. I discuss identity, the identities investigated in this study, and how identity is managed.

For space and place, I define and juxtapose these concepts. Additionally, I speak to the co-constitutive nature of discourse and materiality regarding place and its importance when studying identity. I then address the different ways place has been previously studied in identity work before presenting my final research question. I finish this chapter discussing why I am studying graduate students.

\section{Organizational Change}

First, Zorn et al. (1999) defined organizational change as "any alteration or modification of organizational structures or processes" (p. 10). Reasons for organizational change vary. Change may be used to a) address specific organizational challenges, b) correct past organizational failures, or c) provide opportunities for growth (Lewis, 2019). Organizational change may be implemented strategically to demonstrate 
growth and innovation; change may also be sprung upon organizations by complex organizational environments, forcing a need to adapt to escape or adjust to a crisis (Lewis, 2019). Organizational scholars dispute defining change as a period between times of stability because doing so does not consider that organizations are constantly changing in smaller, less noticeable ways; these scholars argue that major planned change should be assessed in the context of the natural constant change organizations experience (Lewis, 2019; Poole, 2004).

As previously mentioned, organizational change research often juxtaposes unplanned and planned changes. Lewis (2019) differentiated between these two concepts, stating that planned changes are "brought on by purposeful efforts of organizational stakeholders" while unplanned changes are "brought into the organization due to environmental or uncontrollable forces" (p. 39). The COVID-19 pandemic brought unplanned change upon educational institutions that had to be met quickly with "planned" action, that being U.S. universities transitioning to fully online learning.

Organizational change has also been typified by its level of effect at a discursive and/or material level (Zorn et al., 1999) and the size and scope of the change (Bartunek \& Moch, 1987; Lewis, 2019). First-order changes consist of predictable, small disruptions to everyday organizational practice, while second-order changes are large and transformational, deviating significantly from how the organization previously ran (Lewis, 2019). Lewis (2019) warned that the size and scope of an organizational change differs by organizational member; the way one organizational member perceives a change compared to another will vary, depending on how much the change impacts one's life. 
The organizational change examined in this study can and should be observed through a combination of these different perspectives (i.e., planned/unplanned, discursive/material, first-order/second-order) as this organizational change has both planned and unplanned elements, discursive and material impacts, and different effect sizes depending on the organization member. The transition to fully online learning from in-person programs was a major change for organizational members; how members understand and handle the change and its effects is equally important and is discussed next.

\section{Sensemaking}

Sensemaking is not defined as a theory per se-but as a process by which organizational members make sense of unexpected events (Weick, 1995). Maitlis and Christianson (2014) suggested that sensemaking can be triggered by organizational change, identity threats, and organizational crises. Particular to this study, organizational members engage in lots of new sensemaking as the disruption this study investigates incorporates all of these sensemaking triggers (Stephens et al., 2020). Tracy et al. (2006) suggested that sensemaking is most necessary at moments of "tension, paradox, and ambiguity-- moments when not only a sense of the environment is disrupted but also a sense of self" (p. 288). These moments put organizational members at the crossroads of balancing a "desire for restoration" and a "necessity for reflection" (Murphy, 2001, p. $33)$.

The sensemaking process involves three interrelated phases: enactment, selection, and retention. Often, the phases are broken up by phrases from Weick's (2001) question, "How can I know what I think until I see what I say?" (p. 189). "What I say" 
encapsulates the enactment phase (Tracy, 2020). When people choose things to speak about in everyday life, these individuals enact important concepts they wish to talk about or draw attention to. Selection, the second phase, is associated with the "until I see" phrase (Tracy, 2020). During this phase, people select an interpretation of what is being spoken about. Importantly, what is selected need not be the only interpretation, but an interpretation; there are many interpretations one may select. This leads to the third phase, retention, or the "what I think" section of Weick's question (Tracy, 2020). By evaluating a specific interpretation, it is then retained or abandoned for future situations. Weick (1995) argued that sensemaking has seven properties. First, sensemaking is grounded in identity construction. When making sense of a change, people are also (re)constructing their identities. For example, Tracy et al. (2006) assessed how human service workers used humor to make sense of their situations and construct their identities. Second, sensemaking is retrospective; recollecting past events allows individuals to make meaning out of them and predict and guide sensemaking of future events (Dougherty \& Smythe, 2004; Weick, 2001). This idea connects with the third property, that sensemaking is ongoing. How past events are made sense of will influence how similar future events will be assessed. Sensemaking is also a social process. Individuals do not experience events in a vacuum, nor do they construct meaning of said events without others' influence. Additionally, sensemaking involves enactment, meaning that people are not just passive within an environment, but are a part of it (Dougherty \& Smythe, 2004).

Extracted cues are the sixth property of sensemaking and are key to the current project. Extracted cues "are simple, familiar structures that are seeds from which people 
develop a larger sense of what may be occurring" (Weick, 1995, p. 50). During moments that trigger sensemaking, individuals attempt to use cues consistent with past organizational life; however, depending on the event, members may look for new cues to make sense of what is occurring (Dougherty \& Drumheller, 2006; Dougherty \& Smythe, 2004). Sensemaking's final property is that it is based on plausibility, not accuracy. If the sense made is plausible, coherent, and reasonable, it need not be verifiably correct (Murphy, 2001).

Sensemaking's phases and properties are both important in understanding how organizational members manage unexpected disruptions or events. With this major change to higher education, academics have learned and still are learning how to deal with the change, its properties, and its impacts, one of those being impact on identity. As my study focuses on different organization-based identities and how those have been made sense of amidst this major change, I next discuss relevant research on identity and identity management.

\section{Identity}

Identity provides individuals the information to answer the essential questions of "Who am I?" and "How should I act?" (Alvesson et al., 2008; Ashforth et al., 2008; Scott et al., 1998). Kuhn (2006) provided a more communication-centered definition, suggesting that identity is "the conception of the self reflexively and discursively understood by the self” (p. 1340). Communication allows individuals to continually construct one's self-concept, or identity.

Individuals have many social identities that comprise their self-concept. Identity scholars have acknowledged that the many identities one enacts may overlap, compete, 
and even conflict. Tracy and Trethewey (2005) articulated that although studies acknowledge identity as socially constructed and prone to change, organizational members rarely talk about their identities as "fragmented, conflictual, or discursively constituted" (p. 172). Often, organizational members revert to common discourse that situates identity in a dichotomy of real or fake (Tracy \& Trethewey, 2005) or as stable and long-lasting, disempowering members to more accurately and confidently negotiate the tensions that their many identities may have in making up their own self-concept. Meisenbach (2008) articulated how poststructuralist scholars (Ashcraft \& Mumby, 2004; Kondo, 1990; Tracy \& Trethewey, 2005) attempt to demonstrate and demystify an articulation of identity as "fragmented, shifting, conflicting, and lacking in coherence" (p. 261). Knowing this, I hope to similarly articulate identity's complex nature when investigating the many organization-based identities people are making sense of during major organizational change.

Acknowledging identity's complex and prone-to-change nature is especially prominent and important to study during times of major organization change (Alvesson et al., 2008). During organizational change, members of the organization fear losing their sense of identity with the organization, their role, their coworkers, or even their work status (Chreim, 2002). Organization-based identities are extremely volatile during the uncertainty that organizational change brings. Past communication research has assessed changes in identity after mergers and acquisitions (Edwards et al., 2017; Hinsley, 2017; Pepper \& Larson, 2006; Pierce \& Dougherty, 2002) and changes in organizational services and management (Ashcraft, 2005; Barrett \& Stephens, 2017; Rooney et al., 2010), but they skip over assessing the interplay of other organization-based identities 
that members embody. Before discussing identity management, I specify the identities that will be studied. Additionally, I articulate the importance and need to consider the intersection of multiple identities below.

\section{Identities of Interest: University, Department, Graduate Student, \& Teaching} Assistant/Instructor

As early as the late 1980's, organizational scholars have acknowledged the multiple social identities that members might identify with. Ashforth and Mael (1989) suggested that one may have social identities not just derived from the organization at hand, but also "work group, department...age cohort...and so on" (p. 22, see also, Scott et al., 1998). Although identity researchers have acknowledged that individuals have many different identities that should be studied in tandem and separately, most scholars, even Ashforth himself (see Ashforth et al., 2008) condense individuals' many organization-based identities into one organizational identity.

Lammers et al. (2013) and Vough (2012) highlighted the need to study multiple identities together, providing evidence that other organization-based identities such as workgroup, occupational, and relational may operate differently or even in opposition to organizational identities and may have different outcomes often not assessed. Lammers et al. (2013) demonstrated general differences between organizations, workgroups, and occupations, presenting how individuals' identities with such groups may differ. To understand how graduate students have made sense of their different organization-based identities amidst this major change, differentiating between one's different organizationbased identities is necessary. Below I specify the organization-based identities I examine in my study and how they may operate and interact with one another. 
Organizational identity is formed when there is attachment between organizational members and the organization itself (Larson, 2017). For my study, I equate organizational identity with one's university identity. Someone with a welldeveloped organizational identity experiences alignments between the educational institution's values and beliefs and their own.

Identifying with coworkers (or another subunit of the overall organization that may differ from the organization as a whole) represents a workgroup identity. In my study, workgroup identity is thought of as a program or department identity. Research has shown the importance of studying this specific type of organization-based identity as one's workgroup may be where an individual most tightly identifies; this group may be the one individuals most frequently interact with and have the most in common with (Ashforth \& Johnson, 2001; Lammers et al., 2013; Vough, 2012). Work by Ashforth \& Johnson (2001) suggests that lower-order identities, like workgroups, may have more salience, resulting in stronger identity.

Lastly, occupational identity is when one identifies with a specific line of work. I will examine two different types of occupational identity--the graduate student identity and the teaching assistant/instructor identity. Although Ashforth et al. (2008) and Ashforth and Johnson (2001) argued that job or occupational identity sits at a lower-order identity level compared to workgroup or organizational identities, some researchers have argued that occupational identity may actually be a higher-order identity, as it could be seen as more inclusive and transcend across organizations (Lammers et al., 2013; Vough, 2012). By studying each of these organization-based identities, discrepancies between 
how these identities interact can be better articulated (Ashforth \& Johnson, 2001; Meisenbach \& Kramer, 2014).

In summary, Vough (2012) and Lammers et al. (2013) set a precedent for studying multiple organization-based identities at one time. However, little work exists that studies multiple organization-based identities amidst organizational change. Scholars often focus either on organizational identity and change (omitting studying people's many organization-based identities) or the multiple organization-based identities in an organization (not assessing how these are made sense of amid change). This study intends on contributing to this gap by studying how organizational members make sense of multiple organization-based identities amid major organizational change.

\section{Identity Management}

Many different phrases are used to articulate the ways people make sense of their identities, including identity work, identity control, identity regulation, identity construction, and identity negotiation. Identity control and identity regulation encompass the portion of the process that includes the impeding (often organizational) forces on an individual in attempts to dictate or influence their construction of identity, such as discourse or the interests of the organization (Alvesson \& Wilmott, 2002; Kuhn, 2006; Meisenbach, 2008; Pepper \& Larson, 2006; Scott, 2020; Wieland, 2010). That is to say, an organizational members' identities may be regulated and/or controlled by the organizations' interests or by greater societal Discourses. Conversely, identity work and identity negotiation encompass one's individual efforts in defining themselves. Societal or organizational forces may try to regulate/control one's identity, but the way an individual interprets and applies these to their identity is the identity work/construction 
process (Alvesson \& Wilmott, 2002; Kuhn, 2006; Meisenbach, 2008; Pepper \& Larson, 2006; Scott, 2020; Wieland, 2010). Below, I discuss three different strategies for identity management: discursive resources, resistance, and resilience.

\section{Discursive Resources}

Organizational members may attempt to make sense of and manage their identities by drawing on discursive resources. Kuhn et al. (2008) defined a discursive resource as "a concept, phrase, expression, trope, or other linguistic device that (a) is drawn from practices or texts, (b) is designed to affect other practices and texts, (c) explains past or present action, and (d) provides a horizon for future practice" (p. 163). These resources 'guide interactants' interpretation of experience while molding individual and collective action" (Kuhn, 2006, p. 1341). This means that discursive resources can operate as regulation/control for organizational members, but also can allow identity work or negotiation, as the member could choose to adhere to the resource strictly or stray away from it. Thus, discursive resources operate as both an identity control and identity work mechanism (Kuhn et al., 2008; Wieland, 2010).

Most important to the current study is the ideal self discursive resource. Ideal selves operate as what individuals strive or attempt to be (Wieland, 2010). For this study, I examine how participants may use the ideal worker norm and the ideal graduate student norm to manage their identities. Meisenbach and Feldner (2019) defined the ideal worker norm as "a discursive resource that privileges the workplace over anything else" (p. 407). An ideal worker is someone who serves the interest of the organization, who is completely devoted to the organization and their work, and who is readily and always available for the organization (Meisenbach \& Feldner, 2019; Reid, 2015). The ideal 
worker norm operates in many organizational realms and professions, including academia. Some scholars have studied an even more specific idealized self within academia-the ideal graduate student norm. Springer et al. (2009) suggested that academics, especially graduate students, are "monkish in their devotion and slavish in their pursuit of knowledge" (p. 438). The ideal graduate student norm suggests continuous and often simultaneous devotion to writing, teaching, publishing, working with faculty, studying, dissertating, independent research, and additional informal obligations such as service and networking (Eversole et al., 2015; Long et al., 2018; Springer et al., 2009).

The ideal worker norm and the ideal graduate student norm may serve as resources that influence how graduate students make sense of their identities. Organizational members may use these resources as is, benefitting the organization, and in doing so, use them for processes of identity regulation or control. However, members may resist said resources or transform them to better fit their needs, and in doing so, engage the resources in their identity work or negotiation.

\section{Resistance}

Resistance is another way organizational members may respond to organizational change, operating as a type of identity work. For example, hegemonic resistance has been identified as part of expressing identity with a past airline company after a merger (Pierce \& Dougherty, 2002). Organizational members have also communicated resistance by expressing a component of one's identity that may be in conflict with their professional identity (Ferguson \& Dougherty, 2021). 


\section{Resilience}

Resilience has been studied in many academic realms, but Buzzanell (2010) provided communication scholars a way to study the communicative process of resilience, which I believe might be a way organizational members take part in identity work to make sense of their identities after a major organizational change. Buzzanell (2010) suggested several communicative processes involved in creating resilience including "crafting normalcy, affirming identity anchors, maintaining and using communication networks, putting alternative logics to work, and downplaying negative feelings while foregrounding positive outcomes" (p. 1). As my study pertains to identity, the most relevant process of building resilience may be affirming identity anchors. An identity anchor is "a relatively enduring cluster of identity discourses" used when “explaining who they are for themselves" (Buzzanell, 2010, p. 4). However, in making sense of major changes and their impact on one's identities, crafting a new normal may allow organizational members to renegotiate their identities to fit the new situation and make meaning of it.

After reviewing the literature on organizational change, sensemaking, identity, and identity management, I pose the following research questions:

RQ1: How do organizational members communicatively make sense of their organization-based identities amidst major organizational change?

RQ2: How do organizational members engage in identity management during a major organizational change? 


\section{The Role of Space \& Place}

In studying space and place in organizational scholarship, sometimes the terms are thrown about loosely, creating ambiguity. However, generally agreed upon definitions of the terms define space as the objective and measurable entities, while place is viewed as lived space (Cresswell, 2015; Gieryn, 2000; Larson \& Pearson, 2012; Wilhoit, 2016; Wilhoit, 2018). Gieryn (2000) differentiated the two, stating that "space is what place becomes when the unique gathering of things, meaning, and values are sucked out" (p. 465). Wilhoit (2018) provided a useful example in differentiating the two, first seeing a house bought in terms of space--square footage, number of bedrooms and bathrooms, etc. When a family personalizes the house and creates memories there, the objective space transforms into a memorable place.

When differentiating between space and place, the juxtaposition of materiality and discourse can be seen. Many organizational scholars have studied space regarding its material entities, as a location in which an organization exists or the container where the organization lies (Wilhoit, 2016). However, the location of an organization does not just have physical meaning; it is not just objective space, but has socially constructed meaning influenced by discourse. Wilhoit (2018) suggested that limiting one's examination of space just to its material entities neglects how people create meaning of their organizational spaces-turned-places. Examining space/place as socially constructed allows scholars to see space/place as multiple and shifting as well as illuminate the discourses surrounding space/place such as identity and space (Larson \& Pearson, 2012) and power and resistance through space (Wilhoit Larson, 2018). In studying space/place in organizations, materiality and discourse are very much intertwined, both equally 
important to assess. Larson \& Pearson (2012) articulated this idea, stating that "the discursively constructed understandings of place are shaped by (and often shape) the physical/material aspects of place (p. 245). Ashcraft \& Mumby (2004) also spoke of the unescapable entwinement between discourse and materiality when studying organizations. For clarity going forward, I will use "place" when speaking about the space/place combination as I believe place acknowledges both the materiality of space and the social construction that said space also takes on in a more complete manner, a point also argued by Cresswell (2015) and Gieryn (2000).

Scholars studying place have found it to play a key role in identity construction. Specifically, those in the environmental psychology field have long argued the influence place has on the formation of one's self concept (Larson \& Pearson, 2012). Elsbach (2003, 2004) studied the role of physical space and physical markers and how they help establish particular work-related identities in office locations. Also emphasizing the relationship between place and identity, Wilhoit Larson suggested that places where humans dwell, such as their workplace, are "extensions of identity" (p. 395). Rooney et al. (2010) addressed the need for research that investigates the importance of identity and place, expressing the current lack of research investigating "how employees establish social identities linked to the places they inhabit" (p. 46).

When assessing the influence that place may have on organizational members, organizational change is also important to consider. With this study looking at the transition of in-person to online programs, one can argue that this transition also comes with losing the organizational places that in-person learning provided, whether that be classrooms, libraries, a personal office desk, or campus in general. Larson \& Pearson 
(2012) suggested that loss of place can have significant impacts on psychological health. How might this stripping of place impact people's sense of identity? Might the loss of organizational place disproportionately impact specific people? Similar to Rooney et al. (2010), I hope to investigate the connections between place and identity in relation to an organizational change, specifically a change that involves the stripping or loss of place. With this in mind, I pose an additional research question:

RQ3: What role, if any, does place play in organizational members' sensemaking and identity management processes amidst major organizational change?

\section{Graduate Students}

In considering where to explore these issues, studying how more identityprecarious and/or volatile populations handled this change first came to mind. At face value, graduate students may not seem identity-precarious nor volatile. In general, the graduate student population has been studied less compared to other groups, partly due to the assumption that within this life period there is not as much to overcome, as the graduate student journey is just an educational continuation (Tobbell et al., 2010). However, I argue that graduate students are an important group to study for a variety of reasons. Compared to the general population, graduate students are more than six times as likely to experience anxiety and depression (Evans et al., 2018). The anxiety and depression graduate students experience may come from multiple challenges faced by this population, including high expectations and heavy workloads, social isolation, imposter syndrome, and a small and competitive job market (Flaherty, 2018; Langin, 2020; Waldbuesser \& Hosek, 2020). Not only does this population face challenges that accompany the graduate student role, but graduate students must also negotiate multiple 
identities within one's educational endeavors, including the roles of both student and teacher, a department member, and a university member (Foot et al., 2014). How these identities are managed play a major factor in graduate students' persistence through their programs (Austin, 2002; Baker \& Pifer, 2011; Foot et al., 2014). Organizational change research has demonstrated that major change can cause threats to one's many identities (Chreim, 2002). If graduate students' identities and their management are crucial factors in one's persistence towards graduation and general well-being, the need is even more urgent to study how this population makes sense of and manages these identities during major organizational change.

\section{Conclusion}

In this chapter, I addressed the concepts and frameworks that make the rationale for this study. I discussed organizational change and how it results in the need for sensemaking. Then I discussed sensemaking, its phases, and its components. After discussing the main framework in this study, I focused on identity and identity management, presenting two research questions at the end of this section. I transitioned to talking about space and place, asking an additional research question regarding place's role in sensemaking and identity management during change. I concluded this chapter discussing why I chose graduate students for my study. 


\section{Chapter 3: Methodology \& Methods}

In this chapter, I discuss my guiding paradigmatic assumptions as well as the methodology employed for this project. After explaining my stances on these assumptions and how they shaped my methodological plan for this work, I review my data collection process, participants, data analysis, and the validation techniques used.

\section{Paradigmatic Underpinnings}

As a researcher and scholar, my philosophical assumptions align mostly with an interpretive approach. However, some of my stances, especially towards identity management, have post-structural leanings. I first discuss how my stances align with the interpretivist paradigm. Then, I address how my thinking on identity and identity management fits with post-structuralist thinking.

\section{Interpretive Paradigm}

Putnam (1983) argued that interpretive research emphasizes "the study of meanings, that is, the way individuals make sense of their world through their communicative behaviors" (p. 31). This paradigm suggests individuals or groups make sense of their world by communicating socially constructed meanings into existence. In ontological terms, interpretivists assume reality is not out there to be found, but it is created through interaction, language, and interpretation of symbols. Therefore, making sense of one's experience is going to be contextual, subjective, and laden with particular values. Taking an interpretivist approach allowed me to learn and deeply understand the meaningfulness of people's experiences (Schwandt, 2000). As an interpretive scholar, I learned about U.S. graduate students' experiences with the transition from a fully in- 
person to a fully online program, focusing on how they communicatively made sense of and managed their identities during this transition.

Guided by the interpretive approach, I acknowledged my own values and biases due to my background; I did not insist on separating my own values from my research, but I was guided by these values while still being cognizant of how said values affected how I interpreted my participants' experiences. I discuss these values in the selfreflexivity section below. Of utmost importance is this approach's attempt to understand, from the participants' point of view, their subjective experience (Tracy, 2020).

\section{Post-Structural Paradigm}

Although most of my paradigmatic assumptions stem from an interpretive approach, my beliefs about reality have some post-structural leanings. Post-structural researchers find reality to be not just subjectively constructed, but fragmented, fluid, and multi-layered (Tracy, 2020). My participants' experiences revealed such a reality. There were complexities and contradictions within participants' own experiences and when assessing the group as a whole. A post-structuralist paradigm embraces this chaos. Using these paradigmatic assumptions for my own study, I was open to the post-structuralist belief that my participants' experiences might be fragmented, multi-faceted, and fluid; that one's identities may conflict and be layered. Yet, I attempted to provide a constructed meaning (or set of meanings) of this particular experience through my participants' voices and insights that are meaningful.

\section{Methodology}

To investigate my posed research questions, I used a phronetic-iterative approach (Tracy, 2020). Phronēsis, an ancient Greek word, can be translated to "practical wisdom" 
(Aristotle, 2004). Phronetic research is action-oriented, attempting to use data to “illuminate significant problems and contribute to transformation and improvement in relationships, organizations, and societies" (Tracy, 2018, p. 62). Iterative research oscillates between existing theory and pre-determined research questions and goals on the one hand and emergent data on the other (Miles et al., 2013; Srivastava \& Hopwood, 2009; Tracy, 2020). The combination of action-oriented work and the constant iteration between data and theory proved advantageous for this study. I was able to take what I was initially seeing in the data and go back to the literature to learn more about specific concepts or theories and then build on these as I continued analyzing the data.

For example, I started my data collection with existing concepts and frameworks in mind. As this project hinges on how people make sense of an unexpected organizational change, I initially started analyzing data with Weick's (1995) sensemaking framework in mind. Additionally, as I studied how people managed their identities during this change, concepts surrounding identity management and organizational space and place were also interrogated. What emerged from the data helped me narrow my focus on specific elements and properties of these frameworks and concepts to look more into the literature to further guide my analysis.

\section{Participants}

For this study, I enlisted U.S. graduate students who transitioned from attending an in-person higher education graduate program to an online program during the past year. To participate, participants had to be at least 18 years old, a full-time graduate student at a U.S. university, and a teaching assistant/instructor during Spring 2020, when the COVID-19 pandemic halted in-person classes. I focused my study on graduate 
students who were attending public four-year institutions. Participants also had to be U.S. students as international graduate students have been found to have unique experiences distinct from domestic students (Curtin et al., 2013).

I used a combination of volunteer and snowball sampling techniques. Using volunteer sampling meant participants freely chose to take part in my study (Frey et al., 2000). I posted my recruitment call to multiple social network sites. Many people contacted me through these postings while others shared my information on their own social media profiles. Those interested in participating contacted me, were screened for eligibility, and volunteered to be interviewed. In addition to volunteer sampling, I used snowball sampling, asking participants at the end of the interviews if they knew of anyone who may also fit the criteria and want to be interviewed. However, only one participant in the study was recruited through this process. In total, 35 individuals reached out with initial interest in participating. After screening for eligibility, 20 people were eligible. I could not reach and schedule two of these eligible participants. Of the final 18 possible participants, 16 were interviewed due to reaching saturation, which I discuss more in the data analysis section below.

Of the 16 participants interviewed for this study, 10 identified as female and six identified as male. Ages of the participants ranged from 25-38 years old. There were seven master's students interviewed and nine Ph.D. students. My participants came from 10 different states (California, Alabama, Michigan, Arizona, Colorado, Washington, South Dakota, Texas, Missouri, and Massachusetts). Participants' degree programs also varied (communication, literary studies, human development and family studies (HDFS), mathematics, psychology, biology, music, philosophy, rhetoric and composition, theater 
and costume design, and wildlife conservation and management). Of the 16 participants, two identified as South Asian, one identified as Middle Eastern, one as Jewish, and the rest as Caucasian/white. Full participant demographic information can be found in Appendix B.

Methods

Tracy (2020) suggested using respondent interviews when "attempting to understand similarities and differences within a certain cultural group" (p. 159). With this type of interview, participants are asked to speak about their motivations, behaviors, and experiences (Tracy, 2020). Because I wanted to assess how this specific group of people (i.e., U.S. graduate students) made sense of this type of organizational change and managed their identities, I thought this type of interview would be advantageous. These interviews were semi-structured, using an interview guide; however, when unexpected occurrences came up in the interviews, I tried exploring these without strictly adhering to the interview guide.

The interview guide addressed the individuals' identities within their organization or university, their department or workgroup, and their identity with their roles as graduate students and teaching assistants/instructors. These questions asked participants to speak to their sense of identity with each of the chosen organization-based identities and how they made sense of them amid organizational change. I also asked questions regarding place and its importance relating to these identities. The finalized interview protocol can be found in the appendix.

Before starting the data collection process, I conducted one pilot interview with an eligible participant who also conducts qualitative research. Although this participant's 
data was not used in my study's findings, this interview helped address potential concerns with my interview guide and allowed me to practice my interviewing skills. After the pilot interview, I spoke with the participant about their concerns, which included the number of questions in the interview guide and the order they were asked in. Revisions were made to the initial protocol after the interview. Additionally, the pilot participant provided tips about the actual interview process such as probing for more information, providing the formal consent form during the scheduling stage, and how to ask for future potential participants via snowball sampling.

All interviews were conducted via Zoom, a teleconferencing application. Participants were able to choose whether they wanted their cameras on or off for the interview. Additionally, pseudonyms were used to keep participants' experiences anonymous. For all interviews, I was in my private office at my home. I audio-recorded each interview on both the Zoom application and the transcription application, Otter. Upon completion of each interview, I downloaded the automated interview transcriptions generated by the Otter software. I listened to the audio recordings while reading and editing the transcripts to verify them and enhance my own familiarity with the data. The time of interviews ranged from 43 minutes to 89 minutes, with an average time of 62 minutes. Altogether, the 16 interview transcripts amounted to 421 pages of single-spaced text in 12-point Times New Roman font.

\section{Data Analysis}

To analyze the data, I followed Tracy's (2020) guidance for phronetic iterative data analysis. The first step in this process is the data immersion phase, which involves “reading and re-reading, listening, and thinking" regarding one's data (Tracy, 2020, p. 
213). I first read through each interview while cleaning its transcription. While doing this, I noted my initial thoughts for each interview in a separate document. Additionally, during weekly meetings with my advisor, I conversed with her about what I was seeing to further engage with the data.

Once I felt immersed in my data, I started the next phase of analysis. Using MAXQDA software, I primary-coded the interviews via a combination of different techniques, including descriptive, process, and in-vivo coding to capture what was happening in my data. Initially, I primary-coded six interviews. These first six interviews resulted in over 1,100 codes. I found that with this initial trial of coding, I was coding too specific to each interview. Examples from the first trial of data analysis included "shower curtain as makeshift door," "debating an at-home dissertation defense," and "getting chastised about grading speed." After consulting with my advisor, I created a new project in MAXQDA where I focused my efforts much more intentionally with this primary round of coding. After the second attempt at primary-cycle coding, I had 187 first-level codes. Examples of these first-level codes included "business as usual", "keeping connections through technology", and "blurring of boundaries."

While secondary-cycle coding, my focus was on categorizing the first-level codes, finding where the codes could group together around specific theoretical concepts and theories. I used MAXQDA's creative coding feature to visualize the hierarchical process of grouping first-level codes into the secondary-level codes. For example, the first-level code "business as usual" fed into the second-level code of "struggles with graduate student identity," while the "keeping connections through technology" code was further categorized into my "social aspects of sensemaking" secondary-level code. Completing 
secondary-cycle coding, I finished with 22 secondary-level codes. From here, I was able to further categorize these secondary-level codes into the themes discussed in the findings chapters.

I collected and analyzed data until saturation was reached, that is, the point at which new information from the data produces little change to the findings and themes (Tracy, 2020). After conducting 14 interviews and assessing the transcriptions, I felt as though I hit saturation, as no new information emerging from these interviews was distinctly different or novel. I conducted two more scheduled interviews. Interviewee 15's, Jo's, experience was slightly different. Her experience still fit patterns from earlier interviews, but she had different affect towards the change. I demonstrate this difference in chapter five, suggesting how she still created present absences regarding place and identity, but talked more positively about losing specific organizational places compared to my other participants. Interviewee 16's, Alena's, experience did not impact the emergent findings. After interview 16, I felt I hit saturation and ended data collection.

\section{Validation}

Speaking to interpretive work, Angen (2000) suggested that validation "is a judgement of the trustworthiness or goodness of a piece of research" (p. 387). Unlike quantitative work that attempts to verify a study through generalizability and objectivity, validating qualitative work is demonstrated through an ongoing process (Creswell, 2007). There is no one objective truth or a generalizable nature for the questions being asked in qualitative work, so using quantitative criteria to verify qualitative work is counterintuitive and problematic. 
Tracy (2010) emphasized the need for universal, common markers to value qualitative research. The rationale for these universal markers include: a) providing guidelines to help new researchers craft great work, b) connecting qualitative researchers across different paradigms and approaches to promote dialogue about their excellent work, c) demonstrating qualitative work's legitimacy and value, and d) providing audiences tools to "appreciate, respect, and pay attention to" qualitative research (Tracy, 2020, p. 268). In her (2010) article and (2020) book, Tracy suggested eight "big tent" criteria that can be used across methodological and paradigmatic approaches to qualitative work. In my study, I used three big tent criteria to validate my work.

Worthy Topic. Tracy (2010) acknowledged worthy topics to be "relevant", "timely", "significant", and "interesting" (p. 840). Worthy qualitative research topics stem from relevant theoretical work, but also from timely events (Tracy, 2010). For me, this project stemmed from my life in the current pandemic and the effects of this unplanned change on my different spheres of life. This work is not only relevant because of the global pandemic society is currently facing, but the effects of this issue. The pandemic will eventually subside, but the ways the pandemic has affected organizations and the lives of organizational members will be long-lasting. Understanding how this alteration in organizational structures has affected the sensemaking and identities of organizational members is a worthy exploration.

Multivocality \& Member Reflections. For qualitative work, credibility can be established through one's attempts to "express a reality that seems true" (Tracy, 2010, p. 842). Establishing credibility can be accomplished through rich description, triangulation or crystallization, multivocality, and member reflections. I established my work's 
credibility through multivocality and member reflections. Tracy (2020) defined multivocality as the "inclusion of multiple voices" (p. 277). By not limiting the programs or schools that I collected my data from, I collected data from participants from different programs and schools around the nation, which allowed for different experiences to come to light. My participants were from all over the United States in a variety of STEM, social science, and humanities programs. Intentionally recruiting for a range of voices enabled me to capture the many realities my participants faced. Organizational members experienced and made sense of the change in various ways, some of which conflicted internally or between participants. With this project, I did not want to express one objective reality of how this organizational change affected graduate students as a whole. Knowing that change impacts people differently, I interviewed a variety of individuals from different walks of life, allowing me to share the multi-faceted, layered, and complex nature that this experience has and continues to create for U.S. graduate students.

To make sure that my work resonates with my participants' experiences, I employed member reflections. Tracy (2010) defined member reflections as occasions that "allow for sharing and dialoguing with participants about the study's findings, providing opportunities for questions, critique, feedback, confirmation, and even collaboration" (p. 844). By engaging in member reflections instead of member checks or member validation, I further demonstrated my attempt at finding the multi-faceted, layered, and complex realities of my participants. Although member reflections may strive for a correspondence of the participants' experiences and the researcher's interpretation, this process also allows for the participants to provide valuable feedback that may allow for additional insight and credibility (Tracy, 2020). To initiate member reflections, I asked 
my participants at the end of their interview if they would be willing to engage in a member reflection during my write up of the findings. I emailed a summary of the findings to all 16 participants and encouraged any and all commentary, asking if what I interpreted spoke to their experiences. I received responses from seven participants. Four participants described my themes as "interesting" and "fascinating." Two participants, in particular, articulated agreement with the themes outlined. One participant mentioned that they were surprised to see so many others have similar experiences to theirs. None of them suggested additional areas to cover or changes to make in the write up.

Self-Reflexivity. A final big tent criteria I engaged in was self-reflexivity, an aspect of sincerity (Tracy, 2020). Self-reflexivity is especially important in my work. Regarding my axiological assumptions, I believe that research values are an important part of my work and motivated my research interests; being self-reflexive encouraged me to be open about my own beliefs, values, opinions, and biases that have and may continue to shape my work (Creswell, 2007; Tracy, 2020).

My initial interest in investigating this topic came from my own experience of being a graduate student during the unexpected organizational change to online education. Only in my second semester as a graduate student amidst this change, I felt alone, like my connections with my fellow graduate students and being a Missouri Tiger were fading. Because of my own experience in feeling alone and less connected to these identities, I do think that this shaped me into thinking that I had to find a similar reality in my own participants. I constantly reminded myself that I wasn't searching to see if my participants identified more or less with a certain identity, but how they made sense of their identities because of the change. I even spoke with my advisor on occasion about 
my need for a constant reminder in what I was investigating. My participants’ experiences did not have to mirror my own; although many did have some similar experiences, some did not. At times I was caught off guard when a participant told me that they didn't feel as though their identity changed or that they adapted for the better regarding their organization-based identities. I was happy for them that this was their experience, but also I think I was somewhat envious. I had to continually remind myself that my work was to present the range of experiences that this change had on U.S. graduate students on their organization-based identities, even if some differed from my own.

\section{Conclusion}

In review, in this chapter I detailed the paradigmatic assumptions I began this project with, and articulated the methodology I utilized. Then I discussed my data collection process, my participants, and how interviews were conducted and coded. To conclude the chapter, I detailed three validation techniques I engaged in to ensure excellent qualitative work. 


\section{Chapter 4: Findings on Sensemaking \& Identity Management (RQ1 \& RQ2)}

This chapter presents findings related to the research questions on sensemaking and identity management (RQ1 and RQ2). I analyze how participants made sense of and managed their organization-based identities (i.e., graduate student, teaching assistant/instructor, department member, university member) amidst a sudden organizational change. First, I focus on the discursive resources participants used when engaging in these processes, specifically the ideal graduate student norm and the ideal worker norm. I examine how, dependent on the organization-based identity in question, my participants incorporated elements of these resources and/or challenged them.

The second theme I discuss is my participants' two-stage identity sensemaking process. In my interviews, participants indirectly suggested that their sensemaking occurred in two stages. The first stage was characterized by constant support being provided by others and the feeling of being in it together, while the second stage exemplified the dwindling of this support and feeling of being in it together. This twostage process revealed the need for my participants to make sense of their identities more than once amidst this enduring organizational change.

\section{Using Discursive Resources}

To both make sense of and manage their identities, participants utilized two discursive resources, the ideal graduate student norm and the ideal worker norm. Kuhn (2006) suggested discursive resources “guide interactants' interpretation of experience while molding individual and collective action” (p. 1341). Weick (1995) defined extracted cues as "simple, familiar structures that are seeds from which people develop a large sense of what may be occurring" (p. 50). Since discursive resources can guide an 
individual in interpreting an experience, I argue that discursive resources can also act as extracted cues, as they can provide a structure that one may use to make better sense of what is occurring.

The data revealed that, depending on what organization-based identity was in question, the way my participants incorporated these discursive resources (i.e., ideal graduate student norm and ideal worker norm) differed. First, I address how participants used the ideal graduate student norm in their sensemaking and identity management regarding their graduate student identity. After this analysis, I discuss how participants used the ideal worker norm in these processes with their other organization-based identities.

\section{The Ideal Graduate Student Norm \& the Graduate Student Identity}

When it came to one's graduate student identity, participants turned to the ideal graduate student norm. The ideal graduate student norm serves as a discursive resource, guiding how an individual may interpret an experience (Kuhn, 2006). This norm suggests simultaneous devotion to publishing, writing a thesis/dissertation, doing research, graduating on time, teaching, and service (Eversole et a., 2015; Springer et al., 2009). However, how my participants incorporated the ideal graduate student norm in their sensemaking and identity management processes varied. A few participants attempted upholding the idealized version of the graduate student, using this norm as a guide to both make sense of and manage their graduate student identity. Meanwhile, others incorporated elements of being a graduate student such as doing coursework and writing a thesis, but not at the level of the ideal graduate student norm. Others simply did not use 
the ideal graduate student norm at all in their sensemaking and identity management processes.

Barry, a 25-year-old Filipino male graduate student in biology, defined what being a graduate student meant to him, corresponding closely to the ideal graduate student norm. When his program moved fully online in Spring 2020, Barry continued using the ideal graduate student norm to make sense of and manage his graduate student identity. He described how he felt his identity and sense of belonging as a graduate student remained consistent, even after his program moved fully online in Spring 2020:

Since like I'm very much on track to graduate and I associate my, like that identity as a graduate student with like doing research, getting published, and graduating, since all these goals are getting met along the way when we switched to fully online, it stayed the same.

Thus, Barry used the ideal graduate student norm as a cue to help make sense of his identity. Previous literature has demonstrated how during events that generate sensemaking, individuals may explain these events by orienting their attention towards cues that are consistent with their past organizational lives (Dougherty \& Drumheller, 2006; Dougherty \& Smythe, 2004). In this example, Barry enacted and selected a cue (being on track to graduate while simultaneously doing research and getting published) that his own actions aligned with, using this norm to make sense of his graduate student identity, even as much around him was changing. Barry held himself to still hitting these goals (publishing, doing research, graduating on time) that align with the ideal graduate student norm (Eversole et al., 2015; Springer et al., 2009). By enacting, selecting, and 
retaining the ideal graduate student norm, Barry not only made sense of his identity, but he managed it through identity regulation.

Maria, a 37-year-old white female graduate student in rhetoric and composition, also used the ideal graduate student norm when making sense of her graduate student identity after her program transitioned: "I did what I could to continue to write and try to publish. Because I also didn't want to become stagnant and like be, I knew what was still going to be expected of me." Maria specifically drew attention to how, even with her program moving fully online, she felt the continued need to write and publish. She still needed to operate similarly to the expectations of the ideal graduate student norm. The ideal graduate student is one who is constantly writing and publishing, not idly wasting time (Eversole et al., 2015; Long et al., 2018; Spring et al., 2009). Becoming stagnant was not an option for Maria, even during the transition to online learning amidst a global pandemic. Not only did Maria believe these expectations would still be asked of her, but she purposefully enacted, selected, and retained this extracted cue to make sense of her graduate student identity. Since she accepted the ideal graduate student norm and used it to shape her experience with the change, this discursive resource also regulated her graduate student identity. Maria managed her graduate student identity by accepting and upholding the expectations of the ideal graduate student norm.

Some of my participants made sense of and managed their graduate student identity by finishing schoolwork, writing a thesis/dissertation, and graduating on time, but demonstrated this in a less idealized form compared to the ideal graduate student norm. Instead of drawing attention to the undivided and simultaneous devotion and attention aspects of the ideal graduate student norm, my participants made sense of and 
managed their graduate student identity by anchoring themselves to specific expectations of just being a graduate student, like getting through coursework and finishing their thesis/dissertation. Kat, a 26-year-old white female graduate student in communication, expressed that "Schoolwork just kept me grounded. I knew what I had to do." By focusing solely on what she needed to complete the semester (finishing coursework and her thesis), Kat retained her graduate student identity, but not the idealized version. She chose to incorporate some elements of the ideal graduate student norm, while deselecting others. In another instance, Abe, a 32-year-old white male graduate student in wildlife conservation and management, stated "I wouldn't say that my, my identity as a graduate student changed a whole lot with the transition to online, just because of my circumstance of just trying to finish." Abe enacted, selected, and retained the cue of needing to finish his thesis, an element of the ideal graduate student norm, to make sense of what was occurring. However, "just trying to finish" does not demonstrate an ideal graduate student, but just a graduate student. Abe selected specific elements of this discursive resource and deselected others to make sense of and retain his graduate student identity. Writing his thesis made him still feel like a graduate student, so he used this aspect of the norm while challenging the need to do this with undivided attention and devotion. These participants incorporated elements of the ideal graduate student norm such as finishing coursework or a thesis/dissertation, but challenged the need to do so in an idealized form. Thus, they made sense of and retained their graduate student identity by still continuing to execute actions associated with being a graduate student, but did not apply the "ideal" part of the norm in their sensemaking and identity management. 
Explicit challenges to the ideal graduate student norm were not common. The difficulty in fully challenging the ideal graduate student norm regarding one's graduate student identity may stem from the power dynamics at play. Lower-order identities, such as one's job, are more proximal, concrete, and exclusive (Ashforth \& Johnson, 2001). Being a graduate student was more at the core of who my participants were; therefore, challenging expectations regarding this more core identity proved to be difficult. When challenging the ideal graduate student norm did occur, it was done subtly.

A 27-year-old Jewish male graduate student in philosophy, Ozzy was one of the few who discussed challenging the ideal graduate student norm. Ozzy adapted to his program moving fully online by “just like being happier at my home and just enjoying, like, being a person," and "not putting so much stock into being a graduate student." By putting less stock into his identity as a graduate student and putting more into his personal identities, Ozzy demonstrated an act of subtle resistance. He did not prioritize the expectations of an ideal graduate student, but, in fact, deprioritized them. This subtle resistance acted as a way for Ozzy to renegotiate his identities, prioritizing his personal identity over his graduate student identity. He did not use the ideal graduate student norm to make sense of this identity nor to manage it.

\section{The Ideal Worker Norm and Participants' Other Identities}

The other discursive resource my participants drew on to make sense of and manage their organization-based identities was the ideal worker norm. Above, use and application of the ideal graduate student norm varied. Some participants tried upholding this discursive resource while some drew attention to specific elements of the norm and ignored others. For the other organization-based identities investigated in this study (i.e., 
teaching assistant/instructor, department, university), participants mostly engaged in challenging the ideal worker norm. Instead of using the ideal worker norm as a structure to make sense of and regulate one's identities, many of my participants challenged the relevance and use of such norm to manage and make sense of their identities amidst the major organizational change at hand. I will address how participants challenged the ideal worker norm at each of these organization-based identities, starting with the teaching assistant/instructor identity and follow with the department and university identities.

Regarding the teaching assistant/instructor identity, some of my participants challenged the ideal worker norm by resisting rigid teaching expectations. Fatima, a 30year-old Bangladeshi American female graduate student in literary studies, explained how she challenged the ideal worker norm regarding this identity:

I just decided to give everybody an A and like, I said f*** it, like, I don't care. Yeah, I just felt so bad for like everyone trying to navigate this that I just like felt like it was deeply unfair to, like, try to grade them under normal circumstances. And I just like had that moment where I'm like, I'm washing my hands of this. Fatima challenged the ideal worker norm by breaking the rigidity of teaching expectations. Resisting the standards held by the teaching profession, Fatima made sense of her identity as a teaching instructor in a way that did not make her feel ashamed. Additionally, by resisting how an ideal worker in this job may operate, Fatima conducted her own identity work, transforming her teacher identity into what she needed it to be to survive this organizational change.

Kat similarly challenged the rigid instructor expectations, and in doing so, challenged the ideal worker norm. Kat's university and department expected all teaching 
instructors to teach synchronously via zoom for the rest of spring semester. Kat did not agree with this call and decided to hold her classes asynchronously: "My director was really adamant, like you need to see your students at least twice a week...And I was like, no, no, I'm not, because I don't have, I don't have the bandwidth and I'm sure they don't." Although Kat's department very strongly encouraged instructors to host synchronous classes, she didn't believe that this was in students' best interests. Kat stressed how her school "wanted everything to be as usual", but she resisted accepting this frame: I was like whatever. Screw it like, I'm going to do what I need to do to get through the semester, and if my director is mad that I chose to have asynchronous classes because we were in a pandemic. $\mathrm{F}^{* * *}$ it. So I did, like I didn't care.

Kat resisted being an obedient ideal worker expected to follow her department's orders. She challenged the ideal worker norm and conducted her class the way she felt was in students' best interests amidst this major organizational change. By challenging the ideal worker norm and resisting the expectations set by her program, Kat negotiated her identity as a teaching instructor and in doing so, was able to make sense of this identity too.

Nathan, a 29-year-old white male graduate student in human development and family sciences (HDFS), challenged the ideal worker norm regarding his department identity. Nathan confessed how his department still expected its members to embody the ideal worker norm after his program moved online:

Yeah, I was, I was really frustrated. Like that, that the program did not start cutting workloads, did not start cutting assignments...It just, it just felt like it was 
business as usual. You either put up or shut up, you know, you've got to perform. And we're holding you to the same standards.

His program did not make efforts to change expectations of its members; they pushed their members to uphold the ideal worker norm. Although his department accepted the ideal worker norm and attempted to have its members embody it, Nathan challenged this notion, stating that “it wasn't business as usual." Nathan's department enacted the ideal worker norm, but Nathan did not select nor retain this cue.

In managing his department identity, Nathan chose to challenge the ideal worker norm by differentiating himself as much as possible from his fellow graduate students and department members: "I started like getting lots of tattoos and piercings and, it was like a way to cope. It was like a way to cope with the, with the continued expectations, and the drastic change in environment." Through this organizational change and his department's unwillingness to budge on expectations, Nathan felt less and less like he belonged. And because of this, he decided to lean into it and try more and more to differentiate himself. He challenged the ideal worker norm by not selecting and retaining it; he resisted this identity by differentiating himself more and more from his department. Jo, a 38-year-old white female graduate student in theater and costume design, faced a similar situation to Nathan. After her university closed campus and moved all the programs online, Jo’s specific department still asked graduate students to come in and work in-person. This action demonstrated the department's attempt to uphold the ideal worker norm, as the department wanted its members to put the organization above all else and be available to work in-person, even at expense of their students' health and safety. When asked about this experience, she told me: 
I mean, I work in theater. And so, there's a very much, a like 'the show must go on.' I mean I literally heard that from professors, like well 'the show must go on.' It's like no, it literally can't.

Similar to Nathan's department, Jo's department enacted the ideal worker norm, hoping its members would accept this norm, expecting them to embody "the show must go on" mentality. However, Jo refused to select and retain this norm. She challenged selecting and retaining this cue, emphasizing that the show literally could not go on. Her and her fellow graduate students further challenged this norm by resisting to continue work on any of the productions because of the unsafe conditions that the department was attempting to put them in.

In making sense of and managing their identities with their department, Nathan and Jo demonstrated more explicit and direct challenge to the ideal worker norm. However, challenging the ideal worker norm also came in more subtle forms of resistance. Similar to Ozzy resisting the ideal graduate student norm by putting less stock in it, participants used this technique for their department identity too. Putting less stock or effort in one's department identity may seem like a subtle type of resistance, but by being less devoted to the department's interests and needs, this can be seen as a form of challenging the ideal worker norm.

Emma, a 25-year-old white female graduate student in communication, spoke about how the transition to online learning allowed her to take a step back from her department:

I don't feel bad stepping away and not being as like, 'Oh, I should go to this and you know, whatever, just to show my face and show that I want to be a part of this 
group, whatever.' So once it kind of went to online, I'm like okay like I don't have to make those excuses anymore. I can really kind of take a step back.

For Emma, the organizational change allowed her the opportunity to take a step back from being as involved with the department compared to before the transition. Her department identity wasn't as crucial or forced after the transition. By putting less devotion and effort into the department and her department identity, she challenged the ideal worker norm.

David, a 28-year-old white male graduate student in musicology, also challenged the ideal worker norm, but expressed this more with his university identity than his department. The ideal worker norm rests on the idea of organizational members always acting in the interests and needs of the organization (Meisenbach \& Feldner, 2019; Reid, 2015). Even during a major organizational change, an ideal worker would continue prioritizing their organization and wouldn't have issues or struggle with the change. This is where David challenged using the ideal worker norm to make sense of his identity:

There was all this talk of like supporting undergraduate students and like making sure undergraduate students were taken care of. And sort of like, everyone else was expected to just like change, like right away, just like boom you're online now...like I'm a graduate student still, like what about me? And they're like, 'No, you got to like just be prepared, you got to just do it.'

Here, David emphasized that he is still in fact a student and should be given grace and time to process this change, but wasn't. His university expected ideal workers who would not have any issues with this transition and would continue operating business as usual which he grappled with. 
When I asked him to go more into detail about a specific story that highlighted this experience, he had mentioned an incident after the program was fully online where he was late posting grades for a class he assisted teaching for, and in result, was severely reprimanded. He continued grappling with the ideal worker norm being enacted by the university and his refusal to use this norm to make sense of this identity. He vocalized this struggle, "There's all this talk of supporting undergraduate students and like that this is a difficult time for everyone, but like there's no room for me to have a difficult time." Again, David was expected to continue operating as an ideal worker who would have no issue working amidst this major organizational change, but he refused to select and retain this cue enacted by his university.

Summarizing this section, participants utilized two discursive resources to make sense of and manage their organization-based identities, the ideal graduate student norm and the ideal worker norm. Participants used the ideal graduate student norm to make sense of and manage their graduate student identity. How participants incorporated this discursive resource in their sensemaking and identity management varied. For the other organization-based identities investigated, most participants challenged the ideal worker norm. In addition to this finding, how my participants engaged in the sensemaking process was of importance which is the next theme I address.

\section{Stages of Sensemaking}

The other major finding from this study revealed that participants engaged in sensemaking in two distinct stages. When talking to my interviewees about the organizational transition, participants inadvertently differentiated their sensemaking process in two different stages. The first stage was characterized by feelings of support, 
being in it together with fellow graduate students and department members, struggling and commiserating together, and not feeling alone during this transition amidst a greater global pandemic. Conversely, the second stage was characterized by the dwindling of this support and sense of community, forcing my participants to re-make sense of and manage their identities.

\section{Stage 1: Being in it Together with Constant Support \& Community}

When discussing their university's and program's change to online learning, participants discussed how they initially experienced support and efforts to keep a sense of community. Although the transition to fully online learning could have made many feel alone, my participants had mostly positive experiences. Participants perceived that they were going through the change together with their fellow department members and graduate students, that they could commiserate with one another, and that community and support were still being facilitated even without being physically together. The perceptions and feelings of ongoing support and community characterized by this first staged enabled many of my participants to make sense of and manage their identities positively.

"In it Together" while Commiserating Together. Cassandra, a 27-year-old white female graduate student in HDFS, spoke about the feeling of being in the change together with her fellow department members, "Overall, I felt like at least everyone else, like my colleagues, were going through the same stuff, and were supportive in meetings and commiserated together." Because she could commiserate with her colleagues and felt as though she wasn't alone in the process, Cassandra was able to socially make sense 
of the change and her identity with the department. David also spoke of the idea of being in it together with his department:

As a member, like I felt more connected to the department because they, you know, the department was also sort of suffering because of the university's like, not having a plan and just being like, we're going to roll with, in this together.

Because David felt as though he and his department were struggling and "in this together", he was able to keep a sense of connection with this department. Sensemaking's social component encompasses both actual interactions between others and expected interactions (Dougherty \& Smythe, 2004). David may not have actually had conversations with his department members about feeling as though they were struggling or commiserating together, but David's perception of this social component allowed for him to make better sense of what was happening with his identities during this organizational change.

Caroline, a 32-year-old white female graduate student in psychology, relied on social interactions to make sense of her teaching instructor identity. She had never taught online before and neither had many of her fellow graduate students. Talking together about how to move their classes online gave her a feeling of being in it together as well as feeling supported in this endeavor:

It was like we were all in it together. Um, you know, all of us had to, who were teaching, had to quickly figure out how we're going to make our class online when I never taught online, online beforehand. I'd always taught in-person. So a little bit like we're all in this together. 
Caroline felt a sense of camaraderie because she wasn't going through this experience alone. Being able to lean on others during the change and feel as though she wasn't the only one going through it allowed Caroline to make sense not only of her identity with being a teaching instructor, but also her sense of belonging and connection with fellow graduate students.

Philosophy graduate student Ozzy actually lived with another graduate student in his department. They spoke together about the difficulties they were facing when it came to teaching. He articulated some of what he and his roommate discussed:

I definitely think my roommate who was also a teaching assistant helped me out with that because we would always bounce ideas off of each other and, you know, commiserate, and talk about the struggle together. So, that was, that was good. Yeah I didn't feel like I'm just like on my own in this or like I'm having some extreme experience, like a lot of other people are going through this.

Ozzy relied on the conversations with his roommate to know that he wasn't alone during this process, that others were going through the same difficulties too. Speaking with his roommate about the struggle and being able to commiserate and talk together was pertinent for Ozzy in processing the change and how it was impacting his teaching assistant identity.

Continued Community, Connection, \& Support. In addition to feeling in it together with fellow graduate students and department members, also characterized by this first stage of sensemaking was the continued community and connection felt by my participants even with the transition to online learning. When universities moved completely online, participants could have felt a disconnect in their sense of belonging 
with their department, other graduate students, and even their own students. However, my participants spoke about the efforts made in keeping a sense of community and connection going via online avenues.

Because of the transition to fully online learning and the greater global pandemic occurring, people had to find other avenues to socialize and stay connected. Using online applications such as Slack, WhatsApp, Zoom, and other apps allowed for the connection and community with one's department and other graduate students to continue. By fostering conversations and socialization through these online avenues, my participants were able to collectively make sense of and manage their identities. Maria spoke of the use of online avenues to stay connected:

We use WhatsApp. We call it the family chat. We talk all the time. It usually has nothing to do with school. We talk about like, like Tik-Tok videos and memes, a lot to memes. And then also, we all are teaching, and we all, in the spring were teaching the same class...so there was a lot of like, 'Hey this didn't work for me,' or 'Hey this worked for me,' or 'Hey, you know, what reading are you using?' So there was a lot of that too. But I would say that we, we've all dealt with it pretty, fairly well. And I think we all still feel like we belong. And we all still feel connected.

Using online avenues to continue socializing allowed Maria and the other graduate students in her department to still feel a sense of connection and support. Maria made sense of her graduate student and department identity socially by means of these online avenues connecting everyone. 
Gene, a 31-year-old white male graduate student in communication, vocalized how the graduate students in his department used Zoom to host game nights and for “people to constantly check in on one another." Another participant, Emma, mentioned how texting other graduate students in her program was a way to help keep and maintain relationships. Caroline had mentioned how the graduate students in her department used Slack to ask one another questions on taking attendance for the classes they taught. Through these online social interactions, participants were able to collectively make sense of their organization-based identities.

This first stage of sensemaking overall was quite positive. My participants discussed how the feeling of struggling together and relying on one another, as well as keeping connected online, allowed the initial transition to not hit as hard. The constant connection and support felt in this first stage suggests the importance of sensemaking's social component. However, sensemaking is also ongoing. The continued support and connection initially felt in this first stage of sensemaking dwindled, resulting in a second stage of participants' sensemaking.

\section{Stage 2: Dwindling Community, Connection, \& Support}

After the initial stage of sensemaking, which was characterized by feeling supported and connected even with the organizational change, participants discussed a second stage, characterized by feelings of that same connection and support lacking or dwindling. This lack of support and community triggered new sensemaking, highlighting sensemaking's ongoing nature. Gene made sense of this dwindling of support:

For a while I feel like the community aspect that I talked about that's my favorite part of the department I'm in, it kept going...but I feel like even a lot of those ties 
got weaker, over time...I feel like since I've been teaching remotely for almost 11 months now, I don't feel as connected to the university or even really the department at this point. I kind of feel like an island.

In this second stage of sensemaking, Gene felt like an island, alone, and had to make sense of this in relation to his organization-based identities. Kat similarly felt a disconnection with her department as the change to online learning lingered, stating "I felt like we were on an iceberg and it was separating off." Emma also talked of how the support and community characterized by the first stage of sensemaking dwindled with time:

But that [feeling of support and community], I feel like really quickly dwindled as we went further into the end of the semester, where it was still like, yeah we know we can reach out, but like no one really did. We didn't meet as a team anymore...At first there was a lot of like 'we're in it, it's fine' and then I feel like [it] just kind of slowly tapered off.

Initially feeling supported then losing that as the change persisted, Emma had to re-make sense of how she felt regarding her department identity.

Not only did my participants feel a lack of community and support at a department level, but also at the university level. Although most of my participants articulated that they did not have a strong sense of identity with their university to begin with, most of them were happy with how their universities initially handled pulling programs online because of the COVID-19 pandemic. For a lot of them, this decision actually produced a greater sense of belonging with their university as they felt that their university was acting in students' best interests. This greater sense of belonging was 
characterized in the first stage of sensemaking. However, this support also dwindled as universities made decisions for Fall 2020. When Gene's university decided to go back inperson for Fall 2020, this struck a negative cord with him:

When they didn't go online in the fall, I definitely felt worse about the university because I felt like they were endangering a lot of people and they didn't really have a specific plan in place. So for me it wasn't, it didn't help my relationship with the university as a whole.

Originally, Gene was happy with how his university quickly transitioned to online learning. However, his university's decision to go back in-person for Fall 2020 made Gene feel as though his university did not have the students' interests in mind, decreasing his relationship with the university in general. Gene had to re-make sense of his identity at the university level in this second stage of sensemaking.

Cassandra felt similarly to Gene. She was relieved and happy with how her school handled transitioning to online learning in Spring 2020. However, as her school decided to push for in-person classes for Fall 2020, this triggered feeling unsupported by the university. This lack of support forced her to remake sense of the situation. She stated that her university was "very strict and forcing people to teach face-to-face" and that this lack of support in continuing online learning during the Fall 2020 semester made her feel "less positive about the university." Dougherty \& Drumheller (2006) emphasized how "sensemaking is ongoing in duration" (p. 217). As the change went on, and support dwindled or decisions were made triggering a negative feeling, sensemaking had to reoccur, emphasizing its ongoing component. 


\section{Conclusion}

Articulated in this chapter, I presented two major themes relating to the first two research questions of this study. First, I demonstrated how participants utilized the ideal graduate student norm and the ideal worker norm in both sensemaking and identity management processes. Regarding one's graduate student identity, participants varied greatly in how they interacted with the ideal graduate student norm. Some tried upholding the norm in its entirety, some used elements of the norm while deselecting its idealized essence, and others refused using the norm at all. A challenge to the broader overall ideal worker norm was frequently seen when it came to sensemaking and identity management regarding the other organization-based identities (i.e., teaching assistant/instructor, department, university). The second theme I addressed was how my participants' sensemaking occurred in two distinct stages. In the first stage, participants described efforts to keep community and connection between one another. They also mentioned feeling supported, not feeling alone in this change but in it together with their fellow graduate students and department members. However, as time went on, these efforts and feelings dwindled, resulting in participants re-making sense of the change and its impacts on their organization-based identities. 


\section{Chapter 5: Findings on the Role of Place (RQ3)}

In this chapter, I present findings related to the role place played in organizational members' sensemaking and identity management processes during universities’ transitions to online learning. First, I discuss the sensemaking and identity management surrounding the loss of organizational places. Participants mentioned how specific organizational places bolstered feelings of support, collaboration, connection, and community, making them feel a greater sense of belonging with being a graduate student, department member, and even a member of the university. For my participants, losing these places also resulted in losing what these places provided as it pertained to their organization-based identities. Graduate students made sense of their identities by thinking back on what they once had and felt from these organizational places only after they were gone.

After discussing the loss of organizational places, I focus on how the transition to fully online programs resulted in organizational values infusing into my participants homes, blurring the boundaries between work life and home life. Due to the transition, all of one's work operations happened at home; my participants felt as though their home was being intruded upon by their respective organizations. I discuss how this blurring of boundaries and home intrusion affected my participants' sensemaking and identity management regarding their organization-based and personal identities.

\section{Thinking of What Once Was: Creating a Present Absence}

Organizational places played an important role for many of my participants, as they spoke about how specific places provided opportunities for collaboration and connection, contributing to their senses of identities as graduate students, teaching 
instructors, and overall members of their departments and universities. Because of the transition to online learning, all of my participants experienced a stripping or loss of these places. When discussing the organizational change, participants frequently reflected on what was once afforded by a specific organizational place that was now gone, emphasizing place's importance as well as its absence. This recalling of what once was there and now was gone is what past scholars have analyzed as a present absence (Bille et al., 2010; Meyer, 2012). Addressing a present absence, Meyer (2012) mentioned that "the absent is made present through talk and texts, through thought and things" (p. 104). By retrospectively thinking and talking about what was once available to them because of a place which was now gone, my participants made specific organizational places' absences, present. Present absences were utilized in making sense of one's university identity as well as identities at the department, teaching assistant/instructor, and graduate student level.

\section{Present Absences \& University Identity}

A few of my participants spoke about the loss of place and its effects on their identity with the university in general. Gene, a 31-year-old white male graduate student in communication, mentioned how before the change, games and other organizing events provided a sense of connection with his university:

In the past, groups of my cohort and other friends would go to like a football game or a basketball game. There weren't those organizing experiences anymore so I think it definitely did take away some of that [university] identity.

Due to the transition and the campus closing for the rest of spring semester, such experiences afforded by place to feel more of a member of the university were lost. 
Organizing events at specific university locations provided a sense of connection with the university; however, the sense of connection linked to these locations and events was only brought to light after they were no longer available.

Organizing events also proved to be a vital way Maria, a 37-year-old white female graduate student in rhetoric and composition, felt connected to her university. She mentioned specific organizing events such as sports games: "I had several students who were athletes, and they would invite me to their games", as well as her university's international food festival. She spoke about the food festival, stating:

So it was, it was, that was a really cool student experience and that's, those are the things I really miss about being on campus and having that the ability to like learn and experience other cultures because we are such a multicultural campus.

Attending events such as games and the international food festival gave Maria a sense of belonging to her university. She acknowledged missing what these events provided her in a sense of being connected the university after the change.

David, a 28-year-old white male graduate student studying musicology, talked about the difficulties in feeling like a member of the university due to the changes in his physical location. When his university closed down and his program transitioned online, he moved back to his hometown, which he described as changing his sense of connection with the university:

I feel less connected, again just being like, physically like, distant from the university. Because for me like, like the environment, plays a big role. So, like, it's hard to feel like I'm a part of the university when I'm in my house, in my parents' house in [his hometown]. 
Mentioning this loss of place, the university in general, made present its absence and forced David to make sense of how this loss affected his university identity.

Barry, a 25-year-old Filipino male graduate student in biology, was another participant who mentioned the loss of place as tied to feeling less connection to the university. Like David, when Barry's university transitioned fully online, he also moved back to his hometown to live with his parents. Barry struggled feeling like a member of his school after the change:

Since I don't have, like, the same places that I associate with the university, like going to the gym, like all these food places, and the arcade at the university, and I don't have these, like places that I enjoyed at the campus, and I don't see them anymore, I guess it created that further like disconnect and that divide, because I don't have these resources anymore.

Barry recognized what these places offered in terms of connection and belonging with the university once they were no longer available. This recollection in thinking of what once was made the absences of these places present, making him rethink and make sense of his identity with the university anew.

Overall, many participants suggested that the university and its specific places had provided a sense of belonging and connection to their university. Organizing events put on at their universities also made them feel a part of their schools. In the move to online learning, these places and their sensemaking affordances were lost. In recalling what these university locations and events provided after they were no longer available, my participants made these places' absences, present, engaging in the sensemaking process. 


\section{Present Absences \& Participants' Other Identities}

My participants also reflected on the role that place, especially the loss of place, had on their department, teaching assistant/instructor, and graduate student identities. Before the change, my participants discussed how places like their graduate student offices and labs and their department buildings bolstered these organization-based identities by allowing community and connection to be built. Physically losing the office, labs, and department buildings also meant losing the community, belonging, and support these places promoted.

Cassandra, a 27-year-old white female graduate student in HDFS, expressed feeling a loss of community with the loss of her graduate office and department building: “There was a lot less, like I said earlier, like community. There wasn't like walking down the hall [and asking], 'Oh hey, how have you been?'...it was, that community piece disappeared online." The community developed through conversations and hallway chatter, cultivated by the department building and graduate offices, disappeared. Cassandra's looking back and noting this made the absences of these places present because what was provided by these places was now gone. Alena, a 25 -year-old white female graduate student in literature studies, also mentioned noticing the absence of place and its ability to create a sense of community, something she missed: "I lost the community of the other teachers somewhat because we weren't all sharing the office together". In making this statement, Alena made present the absence of community that the graduate student offices promoted. 
Abe, a 32-year-old white male graduate student studying wildlife conservation and management, noted the importance of informal conversations in these organizational places as it related to feeling like a member of the department:

You know if you're at your cubicle, you go to the kitchen or whatever, and you see somebody else from the department. You kind of chat, you kind of catch up or whatever. And you definitely don't, we didn't have that being at home. So I guess I, I wouldn't say that I felt like I wasn't part of the department, but I wasn't an active member of the department.

Being at home meant that the informal chatter stemming from the department building wasn't available anymore. This loss did not result in Abe not feeling like a member anymore, but it did impact him in some way, feeling as though he wasn't as involved or as active of a member.

The informal communication within one's department building was also an important aspect for Caroline, a 32-year-old white female graduate student in psychology:

Um, being there as a graduate student, like faculty office doors are usually open. You can stop in, say hi, ask a question, check in with people kind of informally. And then to have that like all that informal communication removed. So yeah, now everything has to be an email or everything has to be a zoom meeting. And it just like removes that kind of hallway chatter. And I think, honestly, the place is really tied to the people. So I'm not getting to say goodbye to the people, like the faculty I'd worked with. Just being cut off like that, was a pretty big change. 
Caroline made the department building's absence present by emphasizing how after the change, the informal communication disappeared. There was no longer an organizational place that fostered this kind of conversation which impacted her greatly. Near the end of her interview, Caroline emphasized the importance of place again, stating "I think looking back, place was a surprisingly big factor, it played a surprisingly big role in how I felt."

Ozzy, a 27-year-old Jewish male graduate student in philosophy, articulated how his department building allowed for conversations to be had with students and faculty alike. The ability for these conversations to be had is something that Ozzy used as a defining feature of being a department member:

Seeing people that you're only peripherally or like you're not that close with. I do still like to make connections with people who I only know on the surface or I've only hung out with a couple of times. Like, I think that those relationships are a big part of my identity as a grad student in this department or as a grad student, [pause] yeah, in the philosophy department or as a philosopher. Like we get to talk about ideas on a more even playing field. So like being intellectual peers, with a lot of different people...I don't, I don't get to do that anymore because I don't see them in the common areas.

Ozzy had to come to terms with the fact that what he felt was a defining feature of being a member of the department was lost with the loss of these places.

One participant who distinctly referenced the loss of organizational places was Fatima, a 30-year-old Bangladeshi American female graduate student in literary studies. For her, the graduate student office and department building were places where 
collaborations could occur, help could be gained, and general checking in on one another was facilitated. The loss of these places, as she defined as third places, impacted the sense of community felt within her department before:

[The casual interactions have] completely gone away... so to me...the sort of losing of those sort of third places, that are not like home or work, like my office...I sort of lost the ability to kind of like casually interact with people and check in on certain grad students and be like, 'Oh hey, like how are you doing with this thing?'...like so, the kind of opportunity to interact has like completely dwindled. And so, that community does feel a little bit like, like it's not quite there anymore.

Fatima noted that what was offered by these third places like her graduate student office were no longer available, resulting in a loss of community. This sense of community was a defining feature not just for Fatima, but for many of my participants as something that made them feel like a department member and/or was their favorite thing about the department. In their interviews, participants acknowledged the importance of these locations by creating present absences. In doing this, participants made sense of how the loss of place impacted their organization-based identities.

Although the loss of place mostly reduced my participants' senses of organization-based identities, there was one case that the loss of place was beneficial. Jo, a 38-year-old white female graduate student in theater and costume design, spoke of the toxic and hostile environment that was fostered in places like her graduate student office and costume shop. She suggested that these locations were very "hostile" and "mean girl" and did not foster community like other theater programs she had been a part of. When 
asked how, if at all, place impacted her sense of belonging and connection with her department, she mentioned:

We [the other graduate students and I] are much closer now than we were. And a lot of it has to do with that we don't get to see each other every day. So it has, it's because, to communicate with each other and be in touch with each other has to be very conscious.

Place played an equally important role for Jo, but in almost an opposite manner compared to the other participants. Here, losing the toxic and hostile organizational places allowed Jo and her peers to grow closer and develop a greater sense of community and belonging than before.

The loss of organizational places occurred for all my participants. When addressing the loss of these places, my participants brought up what these places once fostered and cultivated that was now gone, recognizing and reflecting on the impact particular places' absences played on their organization-based identities. However, place did not just play a role through its loss; place also played an important role as the loss of organizational places led to an infiltration of one's home place by one's organization, resulting in a blurring of boundaries and identities to be made sense of and managed.

\section{Place, Discourse, and Materiality: A Corporate Colonization}

Participants not only spoke about the loss of specific organizational places, but also addressed how the transition to online learning led to an organizational infiltration of their nonacademic lives. Deetz (1992) argued that the organizational takeover of one's nonwork life by corporate discourse, values, and beliefs, is considered corporate colonization. Because of the move to online learning, specific organizational values 
found their way into participants' homes. Participants accepted these values as part of their sensemaking process, morphing their homes to align with organizational values, specifically those of productivity and professionalism.

Although corporate colonization highly focuses on the discourses, ideologies, and values that pervade the lives of organizational members (Mumby, 2019), my participants also experienced a physical takeover of their home places by their organization, further blurring the boundaries between their work and nonwork lives and their organizationbased and personal identities. I first address how participants incorporated organizational values of productivity and professionalism into their homes. Then, I focus on the blurring of boundaries and identities resulting from the organizations' infiltration of participants' homes.

\section{Incorporating Productivity \& Professionalism into the Home (Place)}

As mentioned, the infusion of one's personal life with corporate discourse is considered corporate colonization (Deetz, 1992; Denker \& Dougherty, 2013). The transition to online learning resulted in the organizational values of productivity and professionalism infusing into my participants' nonwork lives. To make sense of their organization-based identities, participants used these values, transforming their homes to align with them.

Productivity was an organizational value that transferred from my participants' organizational lives into their homes and personal lives. Barry chose places to work from at home that he associated with productivity, "Since I associate the backyard, I began associating the backyard with, like, productivity, like I did with the library and the lab...that's why I chose it is because, like it was a makeshift new productivity 
environment." Barry purposefully subdivided his home to allow for places where he could continue being productive. The backyard became a place colonized by the organizational value of productivity. Gene also used productivity to choose places to work at from home:

So it's all just about comfort, and where I can get, where I feel like I can be most productive. In the office, it's most set up to do research because there's a monitor to go with my laptop so I can do more.

For Gene, his home office became a colonized space as it was conducive for being productive. This organizational value took over Gene's home place; he applied this value, transitioning his home to make sense of and uphold this organizational value amidst the change.

In some cases, the value of productivity was easily infused into my participants' homes and lives. In others, upholding this organizational value at home was difficult. Abe mentioned the struggle of staying productive after the transition. He knew he was still expected to be productive at home, but found that his home places were not as conducive to maintaining productivity:

As far as feeling like a graduate student it, it did feel a little weird kind of like, you know, I definitely wasn't as productive as I could have been had none of this happened. So, you know, and there were times where it was like well, you know I, I wrote a paragraph and that's all I'm going to do today because I don't want to and my bed's right there, whatever.

Productivity was still expected of Abe, even at home. He had to make sense of what his lacking in productivity meant regarding his graduate student identity. 
In addition to productivity, professionalism was another organizational value that pervaded the homes and lives of my participants as they moved to online learning. Participants felt as though they still needed to come off as professional in their identities as teaching instructors/assistants even while operating in their homes. Kat discussed the difficultly in feeling like she was taken seriously as an instructor while living at home: At my parents' house I didn't [have a separate office] so I felt really, like uncomfortable, like figuring out like where I teach, but also like 'Mom, shut up, please don't speak when I'm talking. Like family get out of here.'.... and like, you know, as young, youthful people teaching in higher education, you're always trying to sound like you have your s*** together so your students don't think less of you. Because, especially as a young woman, you know, if my students were to see me and my parents in the background, I was like, 'will they think I'm like less like good at my job?'

Being a young, female instructor already made appearing professional more difficult for Kat; living at home with her parents made the perception of professionalism even more difficult to uphold. Caroline similarly struggled with expectations of professionalism after moving home:

I'm used to like standing up in front of a classroom... and [now], here I am, like my little laptop screen, like sitting on a chair, at home, like, trying to teach...It was definitely a strange experience. And, you know, telling your family like 'Be quiet. I have a lesson, like I have a class in a couple minutes.' So yeah, I think that was definitely a big factor in making me feel like, 'Okay is this really real teaching? Like what is happening?' 
Before, Caroline was teaching in front of a classroom; the abrupt change to now teaching from a small computer screen while attempting to silence her parents before teaching exemplifies how professionalism infused into participants' home places. Caroline still attempted to be a professional teaching instructor at home, demonstrating the organizational value of professionalism intruding her home place and life.

The value of professionalism also pervaded Maria's life. She wanted to uphold being seen as a professional regarding her teaching, and did so in creative ways:

I want to feel professional when I'm teaching. So that's why I got my shower curtain. So that was, I mean it was really hard to be like 'Oh yeah, I'm teaching from my kitchen.' So yeah, the shower curtain is, it was a necessity for me to kind of make sure that I could at least look professional. Even if I didn't necessarily feel that way. Or I mean I guess I always feel that way, but doing it from my home just feels a little less real. I don't really know how to explain it. It's weird, like 'Yeah sure, everybody, take me seriously. While my dog is laying on the couch and my children are screaming in the background. But yeah, I know what I'm talking about.'

To be perceived as professional, Maria used a shower curtain on a rolling rack as a background. She worked in her living room that is open to the kitchen, so using the shower curtain background made her feel as though she demonstrated professionalism, even if it didn't feel that way.

The transition to online learning resulted in workplace values invading my participants' personal spheres. Place played a role here as my participants created and transformed specific places in their homes in attempts at upholding the organizational 
values of productivity and professionalism. However, corporate colonization did not just occur through organizational values taking over the home. My participants felt as though the transition to online learning physically infiltrated their home places, blurring organizational and personal boundaries and identities which they had to make sense of and manage.

\section{Infiltration of Space \& Blurring of Boundaries (and Identities)}

In addition to values of productivity and professionalism pervading my participants' lives, they also mentioned a physical takeover of their homes by their organizations. Originally excited about the prospect of working from home, Ozzy mentioned how he quickly learned that he needed and missed having a place to work that wasn't his home. He stated that the transition to online learning "infiltrated my space". He further explained:

[My graduate student identity] just like, took over my personal identity...the boundaries were blurred between like when I was in my room, you know, watching YouTube videos or when I was in my room watching a lecture. And that's not really good for the way that my, most people's minds work.

Here, Ozzy suggested a physical colonization of place by his corporation; in this study, the corporation being his university and program. Because of having to take and teach his classes all from home, Ozzy felt as though his university and program was physically colonizing his place, impacting both his personal and organization-based identities.

Merida, a 38-year-old white female graduate student in mathematics who was also a single mother, similarly experienced a corporate colonization of her home. Merida spoke to the inability to separate or compartmentalize her work and personal life: 
That's a thing I'm struggling with now, in, you know, doing everything here. Like it's all right here, it's all happening in my living room. Like there's no, there's no borders between things. It's all, it's all in the same place. And so, like, I'll like, you know, hang out with a friend on zoom and we'll be talking and then I'll go to like, you know, division meeting and have to like stop myself from dropping the Fbomb in a division meeting because it's all happening right here.

Transitioning to online learning meant that everything Merida did as a graduate student, a teacher, and a member of her department, happened at home. The boundaries between her personal life and her work life were blurred. Her organization colonized her home place, forcing her to figure out how to make sense and manage this colonization and boundary blurring in relation to her different identities.

Maria, also a mother, was significantly impacted by the corporate colonization of her home place:

It was harder for me to delineate my roles as a mom, and my roles as a student and my roles as a teacher, because it's all, it all happens here all the time. Like there is no like, 'Oh let me stop and put this hat on.'

Here, Maria emphasized an inability to compartmentalize her identities because of the transition. The boundaries of work and life were incredibly blurred for her because of the university and department's colonization of her home. As she said, because everything was happening at home at the same time, she wasn't afforded the ability to stop and transition from being teacher or being student into being mom. It was all occurring in the same place at the same time. She expressed how she missed her workplace: "I felt like it was, it was such a blessing to be able to be at school and just be Maria the student versus 
being mom and Mrs. Nunes." She no longer had an organizational place to help with this separation. The physical takeover of Maria's home by her organization impacted her ability to delineate her personal life and work world as well as her personal identities and organization-based identities, proving to be a difficult hurdle to process in her sensemaking and identity management.

\section{Summarizing Corporate Colonization}

Corporate colonization occurred through the infusion of productivity and professionalism values into my participants' personal lives and by the takeover of their home and the resulting blurring of boundaries due to this unplanned change. Organizational values of productivity and professionalism transferred into my participants' nonwork lives, influencing how they transformed their homes to still fit these values. The transition to online learning also led to some participants feeling as though their home lives and places were being colonized by their organization. The boundaries that organizational places (e.g., the university, graduate offices, department buildings) kept separate were being blurred by the corporate colonization of my participants' homes. This colonization contributed to people's inability to compartmentalize and/or separate their organization-based identities and their personal identities, forcing them to make sense of and manage their identities in relation to place.

\section{Conclusion}

In this chapter, the role place played in participants' sensemaking and identity management was discussed. I found that participants spoke about specific organizational places and what those places offered only after the transition occurred and they no longer had these places. Participants retrospectively made sense of the role place played in 
relation to their organization-based identities by creating present absences. In addition to the loss of place, my participants also mentioned how, with the transition to online learning, the organization and its values invaded their homes and personal lives. This corporate colonization resulted in my participants making sense of their identities by transforming their homes to uphold these organizational values. The corporate colonization also felt like a physical intrusion of my participants' homes by their respective universities and programs, further blurring organizational and personal boundaries and identities, resulting in my participants needing to make sense of and manage their identities in relation to place. 


\section{Chapter 6: Discussion \& Implications}

This chapter summarizes and discusses findings derived from the study's three research questions, theoretical contributions, and practical implications, along with the study's strengths, limitations, and future directions. I begin this chapter discussing how my participants made sense of and managed their identities during a major organizational change. Then, I focus on the role that place played in participants' sensemaking and identity management. I follow with contributions my study makes theoretically and practically. Throughout these sections, I weave in possible future directions. I conclude the chapter with strengths and limitations.

\section{Discussing Sensemaking and Identity Management Processes}

My first two research questions asked how organizational members communicatively engaged in sensemaking and managed their identities during an unplanned organizational change. In what follows I share how participants incorporated discursive resources in their sensemaking and identity management as well as how their sensemaking operated in two distinct stages.

One key finding was participants' utilization of two discursive resources, the ideal graduate student norm and the ideal worker norm. The ideal graduate student norm is a discursive resource that expects students to devote time exclusively to researching, publishing, writing, and teaching, while simultaneously participating in networking and service, among other things (Eversole et al., 2015; Springer et al., 2009). The broader ideal worker norm is a discursive resource that privileges the organization (Meisenbach \& Feldner, 2019; Reid, 2015). Ideal workers are devoted to the organization's needs and interests, are fully committed and available for the organization, and operate with a 
business-as-usual mentality in all situations. Participants revealed how they utilized these discursive resources depending on what organization-based identity (i.e., graduate student, teaching assistant/instructor, department, university) was most salient. My participants engaged in sensemaking and identity management through their use of these discursive resources for each of the identities investigated.

When addressing one's graduate student identity, participants drew attention to the ideal graduate student norm, albeit to various degrees. Some participants tried upholding the ideal graduate student norm in its entirety, such as Maria, who emphasized her need to keep writing and publishing, and to not become stagnant. Ideal graduate students do not stop working nor take breaks (Long et al., 2018). By highlighting how she could not become stagnant, she used this resource as a cue to make sense of and manage her identity. Other participants incorporated specific elements of this resource such as completing coursework and writing a thesis to make sense of and manage their identity, while deselecting the idealized component of this norm. These participants highlighted a need "to just finish" coursework or their thesis/dissertation; they latched onto the portions of this resources that still made sense to them, but being an ideal graduate student was not part of their sensemaking or identity management process. Participants engaged in activities that allowed them to still feel like a graduate student, but challenged being an ideal graduate student, as they felt the relevance of being ideal did not fit the circumstance.

The other discursive resource my participants used was the ideal worker norm. Engagement with this norm was mostly characterized by challenging its relevance as it related to their department and university identity. Because my participants felt less 
connected to being a member of their department and/or a member of their university, they did not feel as much need to uphold the expectations of the ideal worker norm. They challenged being an ideal worker to both their department and their greater university by resisting the business-as-usual mentality and being less devoted or committed to the department's and/or university's needs and interests.

Some of my participants challenged the ideal worker norm when it came to their teaching assistant/instructor identity. Jobs are a type of lower-order identity in Ashforth and Johnson's (2001) framework. Applying this notion to my study, one's teaching assistant/instructor identity might be considered a lower-order identity. When it came to the graduate student, department, and university identities, my findings corresponded with those that suggest people's greater sense of identity are with lower-order identities versus higher-order identities (Ashforth et al., 2008; Ashforth \& Johnson, 2001; Kuhn \& Nelson, 2002); however, challenging the ideal worker norm in relation to participants' teaching assistant/instructor identity, a lower-order identity, did not align with the rest of my findings. Based on the prior research, I would have anticipated less challenge of the ideal worker norm in terms of the teaching assistant/instructor identity.

A second theme related to the sensemaking research question was my participants' allusion to a two-stage sensemaking process. As this organizational change was/is enduring, I found my participants inadvertently divided their sensemaking in two stages. The first sensemaking stage was characterized by continued support, community, and connection along with the feeling of being in it together with fellow graduate students and department members. This stage of sensemaking demonstrated sensemaking as social, as it was through the actual and expected interactions my participants had with 
their fellow graduate students and department members that they were able to make sense of the change and their identities. However, after this initial stage of sensemaking came a second stage of sensemaking. This stage was characterized by the initial support, community, and connection, dwindle, or not be felt anymore. My participants found that the effort to keep community and connection going, and feeling supported, fell through as time went on, prompting a new stage of sensemaking. Sensemaking is ongoing, and in this study, participants described having to re-make sense of their identities as the ways they were able to make sense of them initially did not resonate with how they were feeling as the organizational change continued.

\section{Discussing the Role of Place}

My third research question focused specifically on what role, if any, place played in participants' sensemaking and identity management processes during the change. I found place to be influential in two different ways: place's loss and the resulting organizational intrusion into my participants' lives and places that often were previously outside and apart from the organization.

As described in chapter five, my participants talked about specific places that were important to their senses of identity with being a graduate student, teaching assistant/instructor, department member, and university member. When the transition to online learning occurred, my participants experienced a loss of these organizational places. The loss of access to these places also resulted in a loss of collaboration, connection, and community formerly fostered in these places, impacting my participants' senses of organization-based identities. The participants talked about what they once had because of these places that were no longer available, speaking into existence an absence 
they presently felt. Participants' use of present absences demonstrated how important these places were to my participants and how influential the absence of these places can be (Bille et al., 2010; Meyer, 2012). They had to process or make sense of how the loss of these organizational places impacted their organization-based identities, and did so through creating a present absence.

Losing organizational places also meant the intrusion of the organization into aspects of people's non-work lives. Deetz (1992) argued that the intrusion of corporate discourse and values into one's personal life is considered corporate colonization. Corporate colonization blurs the boundaries between work and home, with the work values dominating the home, something many of my participants experienced. Values of productivity and professionalism became infused into my participants' homes. My participants transformed places in their homes in attempts at upholding these organizational values and making sense of their identities. Additionally, the takeover of my participants' homes by their organizations impacted how they managed their identities, especially balancing their organization-based identities and personal identities. This colonization made it difficult for participants to compartmentalize and separate these identities, creating a further blurring of boundaries tied to physical spaces. At times this meant one's organization-based identities and personal identities were conflicting, such as when Maria was being pulled in different directions by her kids, her professors, and her own students, all in her makeshift office/kitchen. The corporate colonization of place forced my participants to consider how to make sense of and manage these blurred, and often conflicting, identities. Now that I have provided a brief overview of what was found in my study, I will move into how these findings can contribute both theoretically to the 
field as well as provide practical recommendations, all while suggesting possible future directions.

\section{Theoretical Contributions \& Implications}

My thesis makes theoretical contributions to research on sensemaking, identity, and place. First, I bring together research on sensemaking's extracted cues and organizational scholarship on discursive resources to discuss how discursive resources may act as extracted cues people use in sensemaking, while also reaffirming the notion that cues are both selected and deselected. I then reinforce sensemaking's ongoing component, highlighting how sensemaking as ongoing may warrant a need to assess sensemaking in stages more. After focusing on sensemaking, I discuss nested identities, questioning where jobs and/or professions fall on the spectrum and what that means for identity management. Lastly, I address how my analysis suggests that studying place in sensemaking and identity management is beneficial.

\section{Discursive Resources, Extracted Cues, \& Sensemaking}

This study contributes to the existing work on sensemaking in three ways. First, this study extends the theorizing of discursive resources into the sensemaking process. Discursive resources are defined as socially constructed concepts, expressions, or other linguistic devices that guide one's interpretation of an experience while also explaining past and/or future activity (Kuhn, 2006; Kuhn et al., 2008; Kuhn \& Nelson, 2002;

Wieland, 2010). Past research has assessed how discursive resources are used in identity management processes (i.e., identity work and identity regulation) (Kuhn, 2006; Kuhn et al., 2008; Meisenbach \& Feldner, 2019; Wieland, 2010). The current study explains how discursive resources are also heavily drawn on in the general sensemaking process, 
operating as extracted cues that participants oriented their attention to, to make sense of what was happening.

In sensemaking theorizing, extracted cues are defined as familiar structures or frames that people orient their attention to in order to make sense of what is occurring (Boneau et al., 2020; Dougherty \& Drumheller, 2006; Dougherty \& Smythe, 2004; Weick, 1995). Scholars have often assessed extracted cues only as they are enacted in the active sensemaking process; that is to say, past research has focused primarily on cues people speak into existence during the experience being made sense of. For example, Boneau et al. (2020) discussed how informational sources (i.e., doctors, media, coaches, and school administrators) acted as extracted cues that their participants mentioned when making sense of the decision to allow their kids to play tackle football. Participants said that because these informational sources said it was okay for their children to play tackle football, they extracted that cue (the informational source's actual statements of acceptance/permission) to then enact, select, and retain to make sense of their decision.

As much of the sensemaking process is accomplished through extracting cues in one's active sensemaking of a disruptive event, I argue that extracted cues can also be those familiar structures or frames known beforehand that people draw on to understand what is happening. The ideal graduate student norm and ideal worker norm were discursive resources that, prior to the organizational change, were known structures in my participants' lives. To process the organizational change, my participants oriented their attention to these familiar frames and chose to apply and/or challenge them to make sense of their different identities, depending on if they felt the frame still fit after the change. 
Scholarly theorizing about discursive resources acting as extracted cues in the sensemaking process has been alluded to in previous work, but my work contributes to this theorizing by explicitly connecting these ideas and concepts together. In their study on emotions in organizations, Dougherty and Drumheller (2006) found that participants recalled emotions triggered by disruptions of rational behavior such as wasting time or improper work, which constituted extracted cues in their sensemaking. The authors noted that participants extracted these cues "based on the historical expectations of a rational organization" (p. 234), that is, they enacted these cues because they knew of the familiar structure of the rational organization. Rationality in organizations, I believe, is a discourse/discursive resource that these participants drew on in order to make sense of what was occurring. I argue that the extraction of cues do not just come from what's already being enacted directly in the active sensemaking process; people also import familiar structures such as organizational discursive resources and discourses to engage in sensemaking. The ideal graduate student norm and the ideal worker norm functioned as a cue that people drew their attention to, a discursive resource consistent in their organizational lives before, to make sense of the change and its impact on their identities.

Theoretically, this expands the utility of discursive resources; these resources operate not only in identity management, but in sensemaking too. Communication scholars who study sensemaking, especially sensemaking triggered by change, can benefit from this theoretical extension, as this study demonstrated the salience of organizational discursive resources in processing change and the resulting impacts on one's identity. Orienting toward an organizational discursive resource proved important 
for these participants to make sense of what was happening, whether they selected and retained the cue or not.

Second, this project further emphasizes the deselection of cues as part of the sensemaking process and argues that selection/deselection can occur from the same extracted cue. Dougherty and Drumheller (2006) stressed that deselection of specific cues is as important as the enactment and selection of others. In their study, Dougherty and Drumheller (2006) demonstrated how participants selected rationality cues and deselected emotional cues. Boneau et al. (2020) also drew attention to the selection and deselection of particular extracted cues that supported parental decision making. My thesis reaffirms the importance of both selection and deselection in the sensemaking process. Some participants enacted, selected, and retained the ideal graduate student norm while others selected portions of the ideal graduate student norm and deselected others because the norm did not fit after the transition. Additionally, participants mentioned how their departments or universities would enact the ideal worker norm and expect their members to select and retain it. However, my participants mentioned how they did not select nor retain this resource because it was not relevant after the organizational change. Dougherty and Drumheller (2006) and Boneau et al. (2020) addressed the selection of specific cues and deselection of others, but as revealed by this study, the same extracted cue may both be selected and deselected. This finding sheds light on the complexity of discursive resources and their importance not only in identity management, but overall sensemaking.

A final contribution this study makes to sensemaking theorizing is the need to study sensemaking in stages, depending on the type of triggering event and its duration. 
This study's organizational change was not just one event that participants made sense of; as the change was/is ongoing and enduring, there was a need for my participants to make sense and remake sense of what was occurring as the change and its impacts progressed. This study emphasized that sensemaking does not just occur in phases (i.e., enactment, selection, and retainment), but that it can also occur in stages. My participants engaged in sensemaking in two distinct stages during this change. This finding does not just confirm that sensemaking is ongoing, but builds on research that suggests that sensemaking may occur in multiple, distinct stages. In their case study about a sexual harassment incident, Dougherty \& Smythe (2004) found that faculty members engaged in sensemaking in three different phases, each phase emphasizing specific components of sensemaking. Phase one, discovery, and phase three, dispersal, emphasized sensemaking's social and enduring nature-- two components I also found in the two stages of sensemaking my participants engaged in. However, I argue that within one large event that triggers sensemaking, there may be multiple smaller disruptions that result in new sense to be made. This differs from Dougherty and Smythe's (2004) engagement with phases of sensemaking, as I believe these authors used phases to highlight the different components in the sensemaking process of one incident. My contribution of analyzing sensemaking in stages emphasizes that how sense is made at one moment of time during an enduring change may differ drastically from a second point of time. How my participants engaged in sensemaking differed as the change went on. For researchers studying enduring organizational change and sensemaking, special consideration should be taken to see if multiple, distinguishable stages of sensemaking occur. 


\section{Nested Identities}

This study also has implications for research on nested identities. Ashforth and Johnson (2001) argued that within organizations, nested identities exist, with lower-order identities being things like one's job or workgroup and higher-order identities being things like one's department or larger organization. Past research has found that organizational members identify more strongly with lower-order identities compared to higher-order identities (Ashforth et al., 2008; Kuhn \& Nelson, 2002). My findings mostly aligned with the work of these past scholars. My participants felt more connection and greater salience to their lower-order identity of being a graduate student compared to their higher-order identities of being a member of their department and university. However, my participants challenged the ideal worker norm when it came to their teaching assistant/instructor identity, which at first, I considered a lower-order identity, as it could be described as a job. Discussing the meaning behind this finding demonstrates a need for further research to explore the complexities between jobs, occupations, and professions as it pertains to identity.

Challenging the ideal worker norm in relation to my participants' teaching assistant/instructor identity could have really been challenging this norm in relation to their identities with the department and/or greater university, both higher-order identities. Additionally, Lammers et al. (2013) argued that professions may actually operate as a higher-order identity rather than a lower-order identity, as a profession spans past a job, department, and even organization. If my participants felt their identity as a teaching assistant/instructor was a profession rather than just a job, this may have been what gave them more feeling of agency to challenge the ideal worker norm. These findings 
demonstrate the complexity of nested identities and the need to continue studying multiple identities within an organization.

\section{Place, Sensemaking, \& Identity Management}

My project also contributes to organizational communication research that has studied place and its influence on identity (Larson \& Pearson, 2012; Rooney et al., 2010; Wilhoit Larson, 2018). This study contributes to previous research by assessing the role place plays in people's sensemaking and identity management processes, particularly during a major, unplanned organizational change.

My findings suggest a need to assess place's importance on identity and how it fits into people's sensemaking process, especially when talking about loss of place. My participants had to make sense of their identities through retrospectively recalling what was once available to them by these specific organizational locations they no longer had; place as community, collaboration, and support was no longer available, and people had to make sense of how this impacted their sense of organization-based identities. This study contributes to communication research by highlighting that place is an important factor in identity and sensemaking about identity after the loss of such places. Rooney et al. (2010) demonstrated how the physical restructuring and remodeling of a hospital impacted employees' organizational identity differently, with non-supervisors' organizational identification being impacted by the change in place much more significantly than senior managers and supervisors. Their study demonstrated that place did impact people's sense of identity with the organization, especially a loss of certain locations due to the restructuring. However, my study builds on this by not just demonstrating that loss of place is impactful on identities with one's organization, but by 
showing how organizational members make sense of multiple organization-based identities due to the loss of place. These results also help extend the concept of present absence (Bille et al., 2010; Meyer, 2012) into the communication field. This study demonstrates how place is spoken about when it is lost and how participants retrospectively make sense of that loss in relation to their identities. By bringing light to this process, my thesis contributes to how place is talked about in the sensemaking process, especially as it relates to identity and organizational change.

Additionally, this study helps extend Deetz's (1992) corporate colonization beyond discourse and ideology to also take into consideration materiality. Past research on corporate colonization has assessed how corporate discourses, values, and ideologies spill over into other avenues of life, blurring the boundaries between work and life (Mumby, 2019). Most of what is addressed regarding corporate colonization is discourse related; however, the current study found that corporate colonization does not just encapsulate discourse, but that the material colonization of place by one's corporation has an impact. With these findings, I reinforce Wilhoit Larson's (2018) and Larson and Pearson's (2012) push to consider both materiality and discourse when addressing place. Future research should continue to emphasize both materiality and discourse when assessing place, as both the material places and the socially constructed meaning behind them were influential for my participants. Losing the collaboration, community, and support these organizational places provided as well as the physical takeover of my participants' homes by their organizations contributed to how my participants made sense of this organizational change and how they managed their identities. Now that I have 
addressed theoretical contributions and possible future directions in the field, I turn to practical implications and recommendations.

\section{Practical Implications}

My study equips organizations with practical knowledge that can be instilled at both university and department levels to provide a better experience for its graduate students, especially during unplanned organizational changes. Two major recommendations this study provides are (a) helping organizations and their stakeholders deal with ongoing change for its members, and (b) how to demonstrate continued support and community for some of its most out-of-place members of its organization - in this case, U.S. graduate students.

\section{Recommendations for Organizations Regarding Change}

My analysis suggests that making sense of the transition to online learning and its effect on participants' organization-based identities occurred in stages. Most participants discussed an initial feeling of support and continued connection and community that was being fostered. These feelings happened at both the university and department level.

However, this stage did not last, and as the move to online learning persisted, the feelings of support, connection, and community dwindled to a point where my participants felt on their own, causing them to make sense of a severe disconnection and sense of belonging at both of these levels.

Knowing this information, university and program stakeholders and leaders can do a better job at fostering a continued feeling of support and community. The move to online learning occurred in Spring 2020 for all the universities studied, and the transition back to in-person is still happening. Length of organizational change matters and 
stakeholders need to be cognizant of this. If leaders of the university and respective programs can foster feelings of continued support and community during an ongoing and lasting change like this change has proven to be, its members may feel a greater sense of identity at both these levels.

\section{Recommendations for Organizations in Supporting Graduate Students}

In addition to recommendations for how university stakeholders can handle ongoing change, this study also suggests ways universities and their respective programs can support the population of graduate students specifically. When speaking about being a graduate student in general, my participants highlighted how being a graduate student meant having an ill-defined place with their university, feeling not quite like a faculty or staff member, and not quite a student. Participants already felt as though their universities were undergraduate-centric; that their universities were not focused on fostering a positive experience for their graduate students. The liminal and nebulous feeling of being a graduate student as well as not feeling cared for or focused on by their schools was amplified with the organizational change.

Organizational change research has addressed how change is felt differently dependent on the organizational member (Lewis, 2019; Paulsen et al., 2005; Rooney et al., 2010). For members of the organization like graduate students who do not feel cared for or focused on in general, this change further emphasized this discrepancy and created further feelings of disidentification with the organization at its different levels. My participants mentioned how emails going out focused on providing grace and understanding to undergraduate students, but they were not included in this effort. Additionally, when making the initial decision to transfer online, faculty and staff were 
informed and helped make this decision, but again, graduate students were left out. This exclusion caused a continued feeling of liminality in being a graduate student, and furthered a feeling of disconnection after the change. If stakeholders at the university and department level make concentrated efforts to demonstrate their care towards graduate students, this effort could go a long way in creating a more positive environment for these students. For example, leaders at the university and/or department level could offer relief funding for graduate students to offset costs associated with online programing, either of their own classes or classes they teach. One of my participants spoke about how she did not have wireless internet at home; she had to park at coffee shop parking lots in order to use free wireless internet to continue her education. For students like her, funding to help pay for a wireless modem would demonstrate care. One of my participants, David, mentioned that his program was giving additional fellowships to assist the graduate students with funding after the transition to online learning. If departments and universities can make these types of efforts for this population, graduate students could be set up in better positions to carry on and finish their educational endeavors. With these practical implications in mind, I now turn to focus on the strengths and limitations of my study.

\section{Strengths}

This study had three major strengths: the diversity of participants, the timeliness of the subject, and the population studied. First, I recruited a variety of participants from different universities, fields of study, and level of graduate degree. My participants came from universities across ten different states, spanning schools across the nation. Additionally, the fields of study that my participants came from differed greatly as well; 
participants varied in programs within hard sciences, social sciences, humanities, and fine arts. I also had a good mix of both master's students $(n=7)$ and Ph.D. students $(n=9)$. Having a variety of participants from different universities, programs, and regions allowed an array of experiences to be heard. Some of these experiences were similar among my participants while others had unique stories that encompassed this change and its impact on their organization-based identities. This strength demonstrates my drive for multivocality.

A second strength of this project was that it was a timely and relevant topic for many across the nation. Most people today have not seen a global pandemic forcibly shut down and fundamentally change how education institutions operate. The impact of this major change will continue to be studied. Past research has studied identity and belonging specifically for students in online programs (Peacock et al., 2020; Thomas et al., 2014), but studying how a transition to a fully online program that was previously in-person impacts graduate students' senses of identities is something novel and, demonstrated through this study, warrants continued research.

The final strength of this project is the population studied. The purposeful investigation within communication scholarship of graduate students' experiences is not common, and when it is done, the focus is tailored more specifically on things such as work-life negotiations (Long et al., 2018) and cultural identity negotiations (Dutta, 2016). Graduate students are an important population to be studied as their experiences are not often focused on. My participants highlighted the liminal and nebulous space that they occupy as a graduate student. This population holds an identity-precarious position and deserves to be studied. 


\section{Limitations}

Although this project had great strengths and provided contributions theoretically and practically, it is not without its limitations. First, as I attempted to capture my participants' experiences at four different organization-based identity levels, this may have limited the depth to which I could explore each of these different identities. If I were to conduct the project again, I would probably narrow the number of identities I investigated so I could gain a richer knowledge of those I focused on. Additionally, as a newer scholar in the field, this was only my second formal project conducting interviews. That being said, I created and used a detailed interview guide, which may have limited me in getting more nuanced stories and experiences that a more seasoned scholar may have known how to probe for. Although my comfort and skill in interviewing grew substantially during data collection, being less rigid with the use of my interview guide could have allowed me to dig deeper into some of my participants' experiences.

Although this study had great diversity in programs, universities, graduate level, and regions, it was lacking in diversity in other avenues. The majority of my participants were white and all identified within the female/male gender binary. This lack of racial and gender diversity meant that I was unable to see how specific intersections of personal identities with organization-based identities impacted their sensemaking and identity management amidst this change. Even though I was exposed to other personal identities my participants embodied such as being a parent or being neurodivergent, my study could have benefitted from having more diverse racial and gender populations. In addition to this, my study only focused on experiences of U.S. graduate students. This major, 
unplanned organizational change impacted international graduate students in severe and complex ways that was not investigated.

\section{Conclusion}

In this study, I analyzed how organizational members, specifically graduate students, communicatively made sense of and managed their identities amid their university's transition to online learning in Spring 2020. I also assessed what role, if any, place played in these organizational members' sensemaking and identity management processes.

To both make sense of and manage their organization-based identities, participants drew attention to two organizational discursive resources, the ideal graduate student norm and the ideal worker norm. How participants incorporated and used these norms varied and depended on the organization-based identity in question. Also emerging from the data was that, due to the lasting nature of this change, participants' sensemaking occurred in two distinct stages: the first being one characterized by continued support, community, and connection, with the second being characterized by the dwindling and lack of support, community, and connection. These stages resulted in different ways in which my participants made sense of their identities.

Place also played an important role in organization members' sensemaking and identity management processes. Participants associated their graduate offices, labs, and department buildings with collaboration, support, and community. Losing these places due to the organizational change resulted in participants also losing what these places afforded them. My participants made sense of these losses and its impact on their organization-based identities by retrospectively expressing what these places meant to 
them after they were gone. The loss of place also meant an intrusion of place on participants' other realms of life, resulting in corporate colonization. The corporate colonization blurred the boundaries between organization-based identities and personal identities, forcing participants to manage and make sense of these conflicting identities. This study provides theoretical contributions to communication literature surrounding sensemaking and identity management during major organizational change. How discursive resources are utilized in overall sensemaking can help future research address the power of specific discursive resources, especially those related to organizational life. Additionally, this project furthers past researchers' calls to assess the influence of place on identity. Finally, this study provides practical recommendations on assisting some of the most precarious and liminal organizational members in academia, graduate students, during an already tumultuous time in their lives put in even greater disarray due to major, unplanned organizational change. 


\section{References}

Alvesson, M., Lee Ashcraft, K., \& Thomas, R. (2008). Identity matters: Reflections on the construction of identity scholarship in organization studies. Organization, 15(1), 5-28. https://doi.org/10.1177/1350508407084426

Alvesson, M., \& Willmott, H. (2002). Identity regulation as organizational control: Producing the appropriate individual. Journal of Management Studies, 39(5), 619-644. https://doi.org/10.1111/1467-6486.00305

Angen, M. J. (2000). Evaluating interpretive inquiry: Reviewing the validity debate and opening the dialogue. Qualitative Health Research, 10(3), 378-395. https://doi.org/10.1177\%2F104973230001000308

Aristotle. (2004). The Nicomachean ethics (J. A. K. Thomson, Trans.). Penguin Books.

Ashcraft, K. L. (2005). Resistance through consent? Occupational identity, organizational form, and the maintenance of masculinity among commercial airline pilots. Management Communication Quarterly, 19(1), 67-90. https://doi.org/10.1177/0893318905276560

Ashcraft, K. L., \& Mumby, D. K. (2004). Reworking gender: A feminist communicology of organization. Sage.

Ashforth, B. E., Harrison, S. H., \& Corley, K. G. (2008). Identification in organizations: An examination of four fundamental questions. Journal of Management, 34(3), 325-374. https://doi.org/10.1177/0149206308316059

Ashforth, B. E., \& Johnson, S. A. (2001). Which hat to wear? The relative salience of multiple identities in organizational contexts. In M. A. Hogg \& D. J. Terry (Eds.) 
Social identity processes in organizational contexts (pp. 31-48). Psychology Press.

Ashforth, B. E., \& Mael, F. (1989). Social identity theory and the organization. Academy of Management Review 14(1), 20-39. https://www.jstor.org/stable/258189

Austin, A. E. (2002). Preparing the next generation of faculty: graduate school as socialization to the academic career. The Journal of Higher Education, 73(1), 94122. https://doi.org/10.1080/00221546.2002.11777132

Baker, V. L., \& Pifer, M. J. (2011). The role of relationships in the transition from doctoral student to independent scholar. Studies in Continuing Education, 33(1), 5- 17. https://doi.org/10.1080/0158037X.2010.515569

Barrett, A. K., \& Stephens, K. K. (2017). The pivotal role of change appropriation in the implementation of health care technology. Management Communication Quarterly, 31(2), 163-193. https://doi.org/10.1177\%2F0893318916682872

Bartunek, J.M. and Moch, M. (1987). First order, second order, and third order change and organization development interventions: a cognitive approach. Journal of Applied Behavioral Science, 23(4), 483-500. https://doi.org/10.1177\%2F002188638702300404

Bille, M., Hastrup, H., \& Sørensen, T. F. (2010). An anthropology of absence: Materializations of transcendence and loss. Springer.

Boneau, R. D., Richardson, B. K., \& McGlynn, J. (2020). "We are a football family": Making sense of parents' decisions to allow their children to play tackle football. Communication \& Sport, 8(1), 26-49.

https://doi.org/10.1177\%2F2167479518816104 
Buzzanell, P. M. (2010). Resilience: Talking, resisting, and imagining new normalcies into being. Journal of Communication, 60(1), 1-14. https://doi.org/10.1111/j.1460-2466.2009.01469.x

Chreim, S. (2002). Influencing organizational identification during major change: A communication-based perspective. Human Relations, 55(9), 1117-1137. https://doi.org/10.1177/0018726702055009022

Cresswell, T. (2015). Place: A short introduction (2nd ed.). John Wiley \& Sons.

Creswell, J. W. (2007). Qualitative inquiry and research design: Choosing among five approaches. Sage.

Curtin, N., Stewart, A. J., \& Ostrove, J. M. (2013). Fostering academic self-concept: Advisor support and sense of belonging among international and domestic graduate students. American Education Research Journal, 50(1), 108-137. https://doi.org/10.3102\%2F0002831212446662

Deetz, S. (1992). Democracy in the age of corporate colonization: Developments in communication and the politics of everyday life. State University of New York Press.

Denker, K. J., \& Dougherty, D. S. (2013). Corporate colonization and couples' work-life negotiations: Rationalization, emotion management and silencing conflict. Journal of Family Communication, 13(3), 242-262. https://doi.org/10.1080/15267431.2013.796946

Dougherty, D. S., \& Drumheller, K. (2006). Sensemaking and emotions in organizations: Accounting for emotions in a rational(ized) context. Communication Studies, 57(2), 215-238. https://doi.org/10.1080/10510970600667030 
Dougherty, D. S., \& Smythe, M. J. (2004). Sensemaking, organizational culture, and sexual harassment. Journal of Applied Communication Research, 32(4), 293-317. https://doi.org/10.1080/0090988042000275998

Dutta, D. (2016). Negotiations of cultural identities by Indian women engineering students in US engineering programs. Journal of Intercultural Communication Research, 45(3), 177-195. https://doi.org/10.1080/17475759.2016.1165727

Edwards, M. R., Lipponen, J., Edwards, T., \& Hakonen, M. (2017). Trajectories and antecedents of integration in mergers and acquisitions: A comparison of two longitudinal studies. Human Relations, 70(10), 1258-1290. https://doi.org/10.1177\%2F0018726716686169

Elsbach, K. D. (2003). Relating physical environment to self-categorizations: Identity threat and affirmation in a non-territorial office space. Administrative Science Quarterly, 48, 622-654. https://doi.org/10.2307/3556639

Elsbach, K. D. (2004). Interpreting workplace identities: The role of office décor. Journal of Organizational Behavior, 25(1), 99-128. https://doi.org/10.1002/job.233

Evans, T. M., Bira, L., Gastelum, J. B., Weiss, L. T., \& Vanderford, N. L. (2018). Evidence for a mental health crisis in graduate education. Natural Biotechnology, 36, 282-284. https://doi.org/10.1038/nbt.4089

Eversole, B. A. W., Crowder C. L., Lekchiri, S., Clark, A., \& Zimmerman, T. S. (2015). Mothering and professing in the ivory tower: Supporting graduate student mothers. Journal of the Motherhood Initiative, 6(2), 65-80. 
Ferguson, M. W. \& Dougherty, D. S. (2021). The paradox of the black professional: Whitewashing blackness through professionalism. Management Communication Quarterly, OO(0), 1-27. https://doi.org/10.1177\%2F08933189211019751

Frey, L. R., Botan, C. H., \& Kreps, G. L. (2000). Investigating communication: An introduction to research methods. Pearson Education Company.

Flaherty, C. (2018, March 6). Mental health crisis for graduate students. Inside Higher Ed. https://www.insidehighered.com/news/2018/03/06/new-study-says-graduate$\underline{\text { students-mental-health-crisis }}$

Foot, R., Crowe, A., Tollafield, K., \& Allan, C. (2014). Exploring doctoral student identity development using a self-study approach. Teaching \& Learning Inquiry, 2(1), 103-118. https://doi.org/10.20343/teachlearninqu.2.1.103

Gieryn, T. F. (2000). A space for place in sociology. Annual Review of Sociology, 26, 463-496. https://doi.org/10.1146/annurev.soc.26.1.463

Hess, A. (2020, March 26). How coronavirus dramatically changed college for over 14 million students. CNBC. https://www.cnbc.com/2020/03/26/how-coronaviruschanged-college-for-over-14-million-students.html

Hinsley, A. (2017). Developing new organizational identity: Merger of St. Louis public radio and the St. Louis beacon. Journal of Radio \& Audio Media, 14(1), 144-160. https://doi.org/10.1080/19376529.2017.1296445

Ibarra, H. (1999) Provisional selves: Experimenting with image and identity in professional adaptation. Administrative Science Quarterly, 44(4), 764-91. https://doi.org/10.2307/2667055 
Kondo, D. K. (1990). Crafting selves: Power, gender, and discourses of identity in a Japanese workplace. University of Chicago Press.

Kuhn, T. (2006). A 'demented work ethic' and a 'lifestyle firm': Discourse, identity, and workplace time commitments. Organization Studies, 27(9), 1339-1358). https://doi.org/10.1177\%2F0170840606067249

Kuhn, T., Golden, A. G., Jorgenson, J., Buzzanell, P. M., Berkelaar, B. L., Kisselburgh, L. G., Kleinman, S., \& Cruz, D. (2008). Cultural discourses and discursive resources for meaning/ful work: Constructing and disrupting identities in contemporary capitalism. Management Communication Quarterly, 22(1), 162171. https://doi.org/10.1177\%2F0893318908318262

Kuhn, T., \& Nelson, N. (2002). Reengineering identity: A case study of multiplicity and duality in organizational identification. Management Communication Quarterly, 16(1), 5-38. https://doi.org/10.1177\%2F0893318902161001

Lammers, J. C., Atouba, Y. L., \& Carlson, E. J. (2013). Which identities matter? A mixed-method study of group, organizational, and professional identities and their relationship to burnout. Management Communication Quarterly, 27(4), 503-536. https://doi.org/10.1177/0893318913498824

Langin, K. (2020, September 4). As the pandemic erodes grad student mental health, academics sound the alarm. Science. https://www.sciencemag.org/careers/2020/09/pandemic-erodes-grad-student$\underline{\text { mental-health-academics-sound-alarm }}$ 
Larson, G. S. (2017). Identification, organizational. In C. R. Scott \& L. Lewis (Eds.), The international encyclopedia of organizational communication (online edition). Wiley-Blackwell. https://doi.org/10.1002/9781118955567.wbieoc100

Larson, G. S., \& Pearson, A. R. (2012). Placing identity: Place as a discursive resource for occupational identity work among high-tech entrepreneurs. Management Communication Quarterly, 26(2), 241-266. https://doi.org/10.1177/0893318911435319

Lewis, L. K. (2019). Organizational change: Creating change through strategic communication (Second edition). John Wiley \& Sons.

Long, Z., King, A. S., \& Buzzanell, P. M. (2018). Ventriloqual voicings of parenthood in graduate school: an intersectionality analysis of work-life negotiations. Journal of Applied Communication Research, 46(2), 223-242. https://doi.org/10.1080/00909882.2018.1435901

Maitlis, S. \& Christianson, M. (2014). Sensemaking in organizations: Taking stock and moving forward. The Academy of Management Annals, 8(1), 57-125. https://doi.org/10.5465/19416520.2014.873177

Meisenbach, R. J. (2008). Working with tensions: Materiality, discourse, and (dis)empowerment in occupational identity negotiation among higher education fund-raisers. Management Communication Quarterly, 22(2), 258-287. https://doi.org/10.1177/0893318908323150

Meisenbach, R. J., \& Feldner, S. J. (2019). Constructing the ideal worker identity: The rhetorical construction of discursive resources in Undercover Boss. Western 
Journal of Communication, 83(4), 403-422.

https://doi.org/10.1080/10570314.2019.1566564

Meisenbach, R. J., \& Kramer, M. W. (2014). Exploring nested identities: Voluntary membership, social category identity, and identification in a community choir. Management Communication Quarterly, 28(2), 187-213.

https://doi.org/10.1177\%2F0893318914524059

Meyer, M. (2012). Placing and tracing absence: A material culture of the immaterial. Journal of Material Culture, 17(1), 103-110.

https://doi.org/10.1177\%2F1359183511433259

Miles, M. B., Huberman, A. M., \& Saldaña, J. (2013). Qualitative data analysis: A methods sourcebook. Sage.

Mumby, D. K. (2019). Work: What is it good for? (absolutely nothing)-A critical theorist's perspective. Industrial and Organizational Psychology, 12(4), 429-443. https://doi.org/10.1017/iop.2019.69

Murphy, A. (2001). The flight attendant dilemma: an analysis of communication and sensemaking during in-flight emergencies. Journal of Applied Communication Research, 29(1), 30-53. https://doi.org/10.1080/00909880128100

Paulsen, N., Callan, V. J., Grice, T. A., Rooney, D., Gallois, C., Jones, E., Jimmieson, N. L., \& Brodia, P. (2005). Job uncertainty and personal control during downsizing: A comparison of survivors and victims. Human Relations, 58(4), 463-496. https://doi.org/10.1177\%2F0018726705055033

Peacock, S., Cowan, J., Irvine, L., \& Williams, J. (2020). An exploration into the importance of a sense of belonging for online learners. International Review of 
Research in Open and Distributed Learning, 21(2), 18-35.

https://doi.org/10.19173/irrodl.v20i5.4539

Pepper, G. L., \& Larson, G. S. (2006). Cultural identity tensions in a post-acquisition organization. Journal of Applied Communication Research, 34(1), 49-71. https://doi.org/10.1080/00909880500420267

Pierce, T. \& Dougherty, D. S. (2002). The construction, enactment, and maintenance of power-as-domination through the acquisition: The case of TWA and Ozark airlines. Management Communication Quarterly, 16(2), 129-164. https://doi.org/10.1177\%2F089331802237232

Poole, M.S. (2004). Central issues in the study of change and innovation. In M.S. Poole and A.H. Van de Ven (Eds.) Handbook of Organizational Change and Innovation (pp. 3-31). Oxford University Press.

Poulton, P. \& Yoo, R. (2020, July 1). Renegotiating teacher identities: Reflections on student wellbeing and online learning during COVID-19. British Educational Research Association. https://www.bera.ac.uk/blog/renegotiating-teacher$\underline{\text { identities-reflections-on-student-wellbeing-and-online-learning-during-covid-19 }}$

Putnam, L. L. (1983). Paradigms for organizational communication research: An overview and synthesis. The Western Journal of Speech Communication, 46(2), 192-206. https://doi.org/10.1080/10570318209374077

Reid, E. (2015). Embracing, passing, revealing, and the ideal worker image: How people navigate expected and experienced professional identities. Organization Science, 26(4), 997-1017. https://doi.org/10.1287/orsc.2015.0975 
Rooney, D., Paulsen, N., Callan, V. J., Brabant, M., Gallois, C., \& Jones, E. (2010). A new role for place identity in managing organizational change. Management Communication Quarterly, 24(1), 44-73. https://doi.org/10.1177/0893318909351434

Saldaña, J. (2014). Blue-collar qualitative research: A rant. Qualitative Inquiry, 20(8), 976-980. http://doi.org/10.1177/1077800413513739

Schwandt, T. A. (2000). The epistemological stances for qualitative inquiry: Interpretivism, hermeneutics, and social constructionism. In N. L Denzin \& Y. S. Lincoln (Eds.), Handbook of qualitative research (pp. 189-213). Sage.

Scott, C. R. (2020). Identity and identification. In A. M. Nicotera's (Ed.), Origins and traditions of organizational communication (pp. 207-227). Routledge.

Scott, C. R., Corman, S. R., \& Cheney, G. (1998). Development of a structurational model of identification in the organization. Communication Theory, 8(3), 298336. https://doi.org/10.1111/j.1468-2885.1998.tb00223.x

Smalley, A. (2020, July 27). Higher education responses to coronavirus (COVID-19). NCLS. https://www.ncsl.org/research/education/higher-education-responses-tocoronavirus-covid-19.aspx

Springer, K. W., Parker, B. K., \& Leviten-Reid, C. (2009). Making space for graduate student parents: Practices and policies. Journal of Family Issues, 30(4), 435-457. https://doi.org/10.1177\%2F0192513X08329293

Srivastava, P., \& Hopwood, N. (2009). A practical iterative framework for qualitative data analysis. International Journal of Qualitative Methods, 8(1), 76-84. https://doi.org/10.1177/160940690900800107 
Stephens, K. K., Jahn, J. L. S., Fox, S., Charoensap-Kelly, P., Mitra, R., Sutton, J., Waters E. D., Xie, B., \& Meisenbach, R. J. (2020). Collective sensemaking around COVID-19: Experiences, concerns, and agendas for our rapidly changing organizational lives. Management Communication Quarterly, 34(3), 426-457. https://doi.org/10.1177\%2F0893318920934890

Thomas, L., Herbert, J., \& Teras, M. (2014). A sense of belonging to enhance participation, success, and retention in online programs. The International Journal of the First Year in Higher Education, 5(2), 69-80.

https://doi.org/10.5204/intjfyhe.v5i2.233

Tobbell, J., O’Donnell, V., \& Zammit, M. (2010). Exploring transition to postgraduate study: Shifting identities in interaction with communities, practice and participation. British Educational Research Journal, 36(2), 261-278. https://doi.org/10.1080/01411920902836360

Tracy, S. J. (2010). Qualitative quality: Eight "big tent" criteria for excellent qualitative research. Qualitative Inquiry, 16(10), 837-851. https://doi.org/10.1177\%2F1077800410383121

Tracy, S. J. (2018). A phronetic iterative approach to data analysis in qualitative research. Journal of Qualitative Research, 19(2), 61-76. https://doi.org/10.22284/qr.2018.19.2.61

Tracy, S. J. (2020). Qualitative research methods: Collecting evidence, crafting analysis, communicating impact. Wiley.

Tracy, S. J., Myers, K. K., \& Scott, C. W. (2006). Cracking jokes and crafting selves: Sensemaking and identity management among human service workers. 
Communication Monographs, 73(3), 283-308.

https://doi.org/10.1080/03637750600889500

Tracy, S. J. \& Trethewey, A. (2005). Fracturing the real-self---fake-self dichotomy:

Moving toward crystallized organizational identities. Communication Theory, 15(2), 168-195. https://doi.org/10.1111/j.1468-2885.2005.tb00331.x

Vough, H. (2012). Not all identifications are created equal: Exploring employee accounts for workgroup, organizational, and professional identification. Organization Science, 23(3), 778-800. https://doi.org/10.1287/orsc.1110.0654

Waldbuesser, C. W., \& Hosek, A. M. (2020). Graduate student identity salience and mental health. Ohio Communication Journal, 58, 132-144.

Weick, K. E. (1995). Sensemaking in organizations. Sage.

Weick, K. E. (2001). Making sense of the organization. Blackwell Business.

Wieland, S M. B. (2010). Ideal selves as resources for the situated practice for identity. Management Communication Quarterly, 24(4), 503-528. https://doi.org/10.1177\%2F0893318910374938

Wilhoit, E. D. (2016). Organizational space and place beyond container or construction: Exploring workspace in the communicative constitution of organizations. Annals of the International Communication Association, 40(1), 247-275. https://doi.org/10.1080/23808985.2015.11735262

Wilhoit, E. D. (2018). Space, place, and the communicative constitution of organizations: A constitutive model of organizational space. Communication Theory, 28(3), 311-331. https://doi.org/10.1093/ct/qty007 
Wilhoit Larson, E. D. (2018). Feminist organizational placemaking: The relational ontology of place and feminist care. Women's Studies in Communication, 41(4), 394-403. https://doi.org/10.1080/07491409.2018.1551687

Williams, E. A., \& Connaughton, S. L. (2012). Expressions of identifications: The nature of talk and identity tensions among organizational members in a struggling organization. Communication Studies, 63(4), 457-481. https://doi.org/10.1080/10510974.2011.630439

Zahneis, M. (2020, March 26). For many graduate students, Covid-19 pandemic highlights inequities. The Chronicle of Higher Education. https://www.chronicle.com/article/for-many-graduate-students-covid-19pandemic-highlights-inequities/

Zahneis, M. \& June, A. W. (2020, September 3). How has the pandemic affected graduate students? This study has answers. The Chronicle of Higher Education. https://www.chronicle.com/article/how-has-the-pandemic-affected-graduate$\underline{\text { students-this-study-has-answers }}$

Zorn, T., Christensen, L.T., and Cheney, G. (1999). Do we really want constant change? Berrett-Koehler. 


\section{Appendix A: Interview Protocol}

Hello . I'd like to thank you again for taking time to meet with me about my project on identification and identity during change. I am going to ask you some questions about your sense of identity and identification with specific elements of your organization.

**First, I am going to ask you about your university in general as well as your specific department or program:

1. How long have you been at your university? What about in your specific department/program?

2. What things do you like the most about being a part of your university? What things do you like most about being a member of your specific department/program?

3. What things do you like least about being part of your university? What things do you like least about being a member of your specific program/department?

Let's continue by talking about your university's (and department/program's) change to online learning:

1. Tell me the story about how you first learned that your university was moving to online learning.

a. How did finding out about this move to online learning initially make you feel as a member of the University overall?

2. Describe to me the response from your specific department when learning about this change to online learning

a. How did finding out about this change from your department make you feel as a member of the department?

3. How did your sense of belonging with your university change, if at all, when schools transferred online?

a. Describe to me a story that highlights this experience.

b. How did you see it affecting others at your university?

c. Who or what has helped you process this change?

4. How did your sense of belonging with your specific department/program change, if at all, when schools transferred online?

a. Tell me a story or describe an instance that highlights this experience for you.

b. How did you see it affecting your fellow department members?

c. Who or what has helped you process this change?

5. How have you adapted as a member of your university after the change?

a. Do you feel more or less connected to the university after the change? Why?

6. How have you adapted as a member of your specific department after the change?

a. Do you feel more or less connected to your department after the change? Why? 
7. Is there anything else you would like to tell me about the change to online learning and your sense of connection in being a member of your organization before moving on?

**Next, I want to ask you about your occupation/roles at the university, specifically those of being a graduate student and those of being a teaching instructor/assistant.

1. What are your favorite things about being a graduate student? A teaching instructor?

2. What are some of your least favorite things about being a graduate student? A teaching instructor?

Let's now talk about the change to online learning and the specific roles you hold as a graduate student and as a teaching instructor:

1. Tell me about this experience as a graduate student.

2. Describe to me this transition as a teaching assistant/instructor.

3. How did your sense of belonging with your occupation as a graduate student change, if at all, after the transition to online learning?

a. Describe to me a story that highlights this experience.

b. How did you see it affecting your fellow graduate students in their student role?

c. Who or what has helped you process this change?

4. How did your sense of belonging with your occupation as a teaching instructor change, if at all, after the transition to online learning?

a. Describe to me a story that highlights this experience.

b. How did you see it affecting your fellow graduate students in their teaching instructor role?

c. Who or what has helped you process this change?

5. How did you adapt as graduate student after the change? Are you more or less connected to this role after the change? Why?

6. How did you adapt as a teaching instructor after the change? Are you more or less connected to this role after the change? Why?

7. Before moving on, is there anything else you would like to talk to me about regarding your university's transition to online learning and your sense of belonging in being a graduate student? What about for your role as a teaching assistant or instructor?

At this point, I'd like to ask you about places you conduct your work.

1. Before your university moved fully online, where did you commonly conduct your academic work (both student work and teaching)? Describe to me the places you commonly liked to work on your campus, if you did work on campus.

a. Why did you work at these locations? How did working at these locations make you feel? 
2. When your campus transferred online, where did you decide to work for your classes as a student? What about as a teacher? Describe to me how you chose these places.

3. How did your change in place affect your sense of belonging as a student, if at all? What about as a teacher?

4. How did your change in place affect your sense of being a member of your workgroup, if at all?

5. How did your change is place affect your sense of being a member of your organization as a whole, if at all?

Before we wrap up, I'd like to take your information regarding demographic questions

1. Demographics:

a. University (past and current, if different)

b. Length of time at university (at past)

c. Major

d. Age

e. Gender

f. Race and/or identity

g. Relationship Status: single, partner w/out marriage, married, divorced, widowed

h. Do you have children?

i. Preferred contact email

2. As I mentioned in our scheduling email, this project is ongoing and I am utilizing snowball sampling to find participants. I am still seeking more participants who may be interested in the study. Do you know of anyone in your network who would fit the requirements for this project who might want to participate? If so, can you provide me their name and contact information in order to reach out to them?

Thank you again for your time today. I greatly appreciate you taking time out of your day for my study. If you would like to reconnect when I am analyzing my data to see if what I have interpreted speaks to your experiences, please let me know. 
Appendix B: Participant Demographics

\begin{tabular}{|c|c|c|c|c|c|c|c|}
\hline Name & Age & $\begin{array}{c}\text { Race and/or } \\
\text { Ethnicity }\end{array}$ & Gender & $\begin{array}{c}\text { State of } \\
\text { University }\end{array}$ & Program & $\begin{array}{c}\text { Relationship } \\
\text { Status }\end{array}$ & Children \\
\hline Kat & 26 & White & Female & California & Communication & Single & None \\
\hline David & 28 & White & Male & California & Musicology & In a relationship & None \\
\hline Cassandra & 27 & White & Female & Alabama & $\begin{array}{c}\text { Human } \\
\text { Development } \\
\text { and Family } \\
\text { Studies }\end{array}$ & In a relationship & None \\
\hline Caroline & 32 & White & Female & Massachusetts & Psychology & Single & None \\
\hline Maria & 37 & White & Female & Texas & $\begin{array}{l}\text { Rhetoric and } \\
\text { Composition }\end{array}$ & Married & Two \\
\hline Gene & 31 & White & Male & Missouri & Communication & Married & None \\
\hline Merida & 38 & White & Female & California & Mathematics & Single & One \\
\hline Barry & 25 & Filipino & Male & California & Biology & Single & None \\
\hline Ozzy & 27 & Jewish & Male & Colorado & Philosophy & In a relationship & None \\
\hline Abe & 32 & White & Male & Arizona & $\begin{array}{l}\text { Wildlife and } \\
\text { Conservation }\end{array}$ & In a relationship & One \\
\hline Nathan & 29 & White & Male & Alabama & $\begin{array}{c}\text { Human } \\
\text { Development } \\
\text { and Family } \\
\text { Studies }\end{array}$ & Single & None \\
\hline Tracy & 28 & Middle Eastern & Female & Michigan & Communication & In a relationship & None \\
\hline Emma & 25 & White & Female & South Dakota & Communication & Married & None \\
\hline Fatima & 30 & $\begin{array}{c}\text { Bangladeshi } \\
\text { American }\end{array}$ & Female & Washington & Literary Studies & In a relationship & None \\
\hline Jo & 38 & White & Female & California & $\begin{array}{c}\text { Theater \& } \\
\text { Costume Design }\end{array}$ & Single & None \\
\hline Alena & 25 & White & Female & Michigan & Literary Studies & In a relationship & None \\
\hline
\end{tabular}

